University of Zurich

Department of Economics

Working Paper Series

ISSN 1664-7041 (print)

ISSN 1664-705X (online)

Working Paper No. 277

\title{
Demand Forces of Technical Change Evidence from the Chinese Manufacturing Industry
}

Andreas Beerli, Franziska J. Weiss, Fabrizio Zilibotti, and Josef Zweimüller

January 2018 


\title{
Demand Forces of Technical Change Evidence from the Chinese Manufacturing Industry*
}

\author{
Andreas Beerli† Franziska J. Weiss ${ }_{\ddagger}^{\ddagger}$ Fabrizio Zilibotti, ${ }^{\S}$ and Josef Zweimüller $\mathbb{I}^{\mathbb{I}}$
}

January 18, 2018

\begin{abstract}
This paper investigates the effect of domestic market size on innovation activities across different durable good industries in the Chinese manufacturing sector. We address the endogeneity of market size by an IV strategy, based on a measure of potential market size, which is driven only by changes in the Chinese income distribution. This measure is exogenous to changes in prices and qualities of durable goods and is a valid instrument for expected future market size. Our results indicate that an increase in market size by one percent leads to an increase in firm-specific total factor productivity by 0.46 percent and an increase in labor productivity by 0.50 percent. These findings are robust to controlling for export behavior of firms and supply side drivers of R\&D.
\end{abstract}

Keywords: China, Demand-Induced Innovation, Directed Technical Change, Durable Goods, Economic Growth, Engel Curves, Market Size, Middle Class, Non-homothetic Preferences.

JEL classification: D31, L11, L68, O31, O33.

\footnotetext{
${ }^{*}$ We thank seminar participants at the University of Zurich, ZEW, DEGIT XVII, RES 2013 and Berthold Herrendorf, Christian Helmers, Andrea Ichino, Guy Michaels, Uwe Sunde, Nico Voigtländer and Xiaodong Zhu for valuable comments and discussions. Xiaojun Chen, Lingqing Jiang, Yung-Chieh Huang, Matthias Schief, Xiang Wei and Damian Osterwalder provided excellent research assistance. Andreas Beerli and Fabrizio Zilibotti gratefully acknowledge financial support from the European Research Council (ERC Advanced Grant IPCDP-229883). Franziska J. Weiss acknowledges financial support from the Swiss National Science Fundation. Josef Zweimüller was supported by the Swiss National Science Foundation under the SNF Sinergia grant CRSII1 154446 "Inequality and Globalization: Demand versus Supply Forces and Local Outcomes."

${ }^{\dagger}$ ETH Zurich, KOF Swiss Economic Institute and Immigration Policy Lab, E-mail: beerli@kof.ethz.ch.

${ }^{\ddagger}$ E-mail: franziska.j.weiss@gmail.com.

§Yale University, E-mail: fabrizio.zilibotti@yale.edu

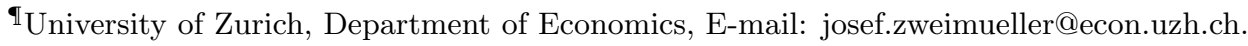




\section{Introduction}

The economic growth of China is characterized by a formidable increase of productivity in the industrial sector. Fast productivity growth has multiple sources. On the one hand, it proceeds from the reallocation through the selection of more productive firms (Song et al. 2011; Hsieh and Song 2016). On the other hand, it results from active investments in technology adoption and adaptation (Acemoglu et al. 2015; Holmes et al. 2015). Zilibotti (2017) argues that a shift from capital accumulation to innovation is a necessary condition for Chinese growth to continue on its fast-converging trajectory.

If investments aimed to improve productivity are becoming more and more important over time, what is their driver? According to the theory of directed technical change (e.g., Acemoglu and Zilibotti 2001, Acemoglu 2002, henceforth DTC) market size is an important determinant of such investments. While the theory DTC focuses on the introduction of new frontier technologies, Gancia et al. (2013) show that market size is also crucial for what they call "directed technology adoption." Their argument echoes the pioneer study of Grilliches (1957) documenting that the introduction of a superior technology, hybrid corn, was faster in US states with a larger domestic market size.

One might question whether domestic market size matters in a globalized economy, especially in an export-oriented economy like China. In the earlier stage of its economic boom, China's growth was largely driven by the export of low value-added goods (textiles, toys, etc.) whose markets were abroad. However, there is also an immense demand potential coming from China's large domestic market and from its emerging middle class. Since 1978, economic growth lifted over half a billion people out of poverty. The process was associated with the emergence of a new class of consumers with discretionary income to spend on consumer goods that satisfy less basic needs. To which extent does (or will) the growing middle class fuel growth and technical change in the Chinese manufacturing industries? This paper asks whether - and to which extent - the expansion of the local market for consumer durables stimulates productivity-enhancing investments by Chinese firms, thereby contributing to the surge of technical progress in Chinese manufacturing.

Our empirical investigation is motivated by recent theories that combine DTC with non-homothetic preferences (NHP), including Foellmi and Zweimüller (2006) and Boppart (2011). The theory of DTC predicates that firms' investments in new technologies hinge on a market size effect: as the demand for a good produced by a particular industry increases, firms in such an industry invest more in the creation or adoption of new technologies relative to industries in which demand is sluggish. The theory of NHP predicts, in turn, that economic growth affects the sectoral composition of domestic demand. It is wellknown, for instance, that economic development and the formation of a middle class reduces the food share of consumption and stimulates the demand of durable consumption goods. If, in addition, there is a hierarchy in the consumers' purchase of durable good (e.g., as they grow richer, households purchase first a motorbike, and then a car) the process of economic growth is characterized by waves of expansion of the domestic market for different durable goods. Merging the insight of the two theories yields the prediction that economic growth brings about demand-driven waves of technical progress: the expectation of a future market size expansion for the product of a particular industry causes a boom in innovative activities in that industry ${ }^{1}$

To establish an empirical link between expected market size and technical progress, we

\footnotetext{
${ }^{1} \mathrm{~A}$ formal argument of the link between DTC and NHP is provided in Boppart and Weiss (2013).
} 
combine data from two different sources: the Chinese Health and Nutrition Survey (CHNS) which provides information on consumption behavior of households; and the Annual Survey of Industrial Production (ASIP) from which firm-specific productivity measures (and their changes over time) can be calculated. We concentrate on 16 industries covering a substantial share of expenditures for consumer durables: cellphones, cars, computers, telephones, refrigerators, home video appliances, washing machines, air conditioning, cameras, satellite dishes, motorcycles, kitchen appliances, radios, sewing machines, electric fans and bicycles.

A potential problem with our empirical analysis is the endogeneity of market size. Technical progress can be the trigger rather than the effect of the expansion in the domestic market of a specific product, e.g., by causing a fall in its sale price. To tackle the endogeneity problem we exploit the enormous variation in the distribution of household incomes associated with Chinese economic growth during the last two decades.

In 1990, less than 17 percent of Chinese households fell into the category of high-middle income and high-income households. By the year 2011, the share of households in these income categories has increased to 74 percent (20 percent high-middle and 54 percent highincome). During the same period, the share of low-middle income households decreased from 37 to 12 percent, while the share of low-income households fell from 46 percent to 14 percent ${ }^{2}$ These changes lead to predictable, differential changes in demand across various consumer goods industries. For instance, to return to the previous example, the market for motorcycles booms earlier than the market for cars. However, at some point, the former becomes saturated, and the potential for future market expansion dies off. At that point, it is the car industry that starts attracting investments and innovative activities. It is this source of variation that forms the basis of our strategy to identify the impact of expected demand on technical change in Chinese manufacturing industries.

More precisely, we construct product-specific Engel-curves for the 16 consumer durables, and estimate changes in expected market size for each durable good. We first fix incomegroup specific ownership rates of a particular durable good to a particular base-year and then use the changing population shares across income classes to calculate a measure of potential ownership and potential market size in other years. This yields an industryspecific markets size measure, whose evolution over time is entirely driven by changes in the income distribution. Changes in ownership patterns of a given income group, which might be induced by changes in prices or the quality of goods, do not affect this potential market size measure. To the extent that these differential changes in expected markets size are uncorrelated with unobserved factors that drive innovation incentives, our market size measure identifies the impact of expected demand on technical change in Chinese manufacturing.

We find quantitatively important demand effects on technical change: a one percent increase in expected market size increases firm-specific TFP by 0.46 percent and firm-specific labor productivity by 0.50 percent. Hence our findings suggest that firms in industries

\footnotetext{
${ }^{2}$ We group households from the China Health and Nutrition Survey (CHNS) into four income groups according to the quartiles of the pooled income distribution 1997-2006 using their annual household income per capita in constant 2011 Yuan: low income (below 2'293 Yuan), lower middle income (2'294- 4'539 Yuan), upper middle income (4'540 - 8'136 Yuan), high income (8'137 Yuan or more). In constant 2011 USD (PPP adjusted), this corresponds roughly to: below USD 654, USD 655 -USD 1294, USD 1295 USD 2'320, USD 2'321 or more. This classification ensures that we measure durable good usage in all income groups accurately over a long time period. These income thresholds used here are lower than the conventional classification used by the World Bank Atlas method, which uses the following brackets (2011 USD): 0-1'025, 2'150-4'034; 4'035-12'474, and 12'475 or more.
} 
with a large expected local market have increased their productivity more strongly, and show also higher levels of other measures of innovative activity.

The estimated effect of expected market size is robust to a number of checks. First, we include a rich set of firm-level determinants of $R \& D$ and market concentrations, in particular foreign and government ownership, as some scholars pointed out that this may affect productivity to a considerable degree (Van Reenen and Yueh, 2012). Second, we show that our results are robust to supply-side drivers of $R \& D$ affecting innovation opportunities of Chinese firms by including different measures of worldwide technology potential reported by firms in the US and Switzerland operating in the same durable good industries. Third, our findings are robust when we control for a firms' export status. This is particularly important in the context of China, as the Chinese economy is strongly export-driven, so demand conditions on export markets may be more relevant for productivity and technical progress than domestic demand. We test for the robustness of our results controlling for firms' export behavior. Interestingly, in our dataset there is a stark dichotomy between exporting and non-exporting firms. About $54 \%$ of the firms in our sample do not export at all, whereas for $21 \%$ of them exports account for more than $75 \%$ of their total sales $3^{3}$ It turns out that the domestic market size effect is insignificant for exporting firms. Instead, our results are entirely driven by non-exporting firms serving exclusively the Chinese market. This is coherent with our hypothesis that innovative activity is driven by the expectations of future market size. What matters for exporting firms is the global market. For these firms, the expansion of the domestic market size is less important. For non-exporters, however, technology adoption behavior strongly hinges upon expectations of the domestic market size. For instance, a car producer serving the local market will react to the expansion of the Chinese middle class. In contrast, the investment behavior of an assembling firm producing cameras that are exported globally will not be affected by local market size expectations.

Empirical studies thoroughly examining the effect of market size on innovation remain relatively scarce with most papers focusing on the pharmaceutical industry. Acemoglu and Linn (2004) document a causal link between market size and innovation building on differential patterns of drug use between young and old individuals. Exploiting the demographic changes in the U.S. population as exogenous source of variation in market size, they find a positive effect of expected demand on innovation across different drug categories. Their findings are quantitatively important and very robust. A one percent increase in potential market size leads to approximately a $4 \%$ increase in the entry of new non-generic drugs. Finkelstein (2004) demonstrates that health policies designed to increase utilization of vaccines created strong incentives to develop new vaccines. According to her estimates, a 1 dollar increase in expected annual revenue for vaccines generates additional 6 cents of investment in that vaccine. Moreover, these policies were associated with a 2.5 -fold increase in clinical trials for new vaccines. Contrasting evidence comes from Acemoglu et al. (2006b) who investigate the effect of Medicare on the development of new pharmaceuticals for the elderly. They find no evidence that the introduction of Medicare is associated with an increase in drug consumption among the elderly. Consistent with this, they also find no evidence of an increase in the approval of new drugs more likely to treat diseases that affect the elderly, after Medicare's introduction. Blume-Kohout and Sood (2012) consider the market size increase for prescription drugs through Medicare Part D which increased

\footnotetext{
${ }^{3}$ To be precise, it may be that one firm exports in one year but not in the next year. Shares are taken with respect to the pooled sample.
} 
pharmaceutical firms' expected sales. They find a significant increase in pharmaceutical R\&D for therapeutic classes with a higher Medicare market share. De Mouzon et al. (2015) use detailed data on spending patterns of patients (and their insurers) to show that expected market size has a highly significant and quantitatively important effect on innovations (as measured by the number of new chemical entities of the market of a particular disease class.)

The above findings all indicate a large impact of expected market size on innovative activities but they are specific to the pharmaceutical industry. It is not clear whether empirical evidence from the pharmaceutical industry applies to other industries as well. Boppart and Weiss (2013) focus on demand effects on R\&D in the whole U.S. industry. Using the input-output structure of different industries as an instrument for actual market size, it turns out that a sector's market share has a significant positive effect on sectorspecific R\&D investments.

Our paper is also related to the literature studying the determinants of the recent sharp increase in $R \& D$ and patent activity in China. R\&D expenditures as a fraction of GDP roughly tripled in China from $0.6 \%$ in 1996 to over 1.8\% in 2011 (The World Bank 2014). While an increase in R\&D intensity is a common pattern over the development process, this has started when China has still a very large technology gap from the frontier. Taiwan, for comparison, reached the same R\&D-to-GDP ratio in 1995 as did China in 2009, when its GDP per capita was twice as large as China in 2009. Some recent studies argue that this exceptional pattern is partly due to the opportunities provided by the presence of a large domestic market. Gao and Jefferson (2007) argue that large and fast growing consumer markets create a premium for research-intensive industries to establish production centers in close proximity to burgeoning-consumer markets. Hu and Jefferson (2008) go further and suggest that an important driving force could be the changing composition of domestic consumption shifting away from products with low-technology content (such as bicycles) to goods and services that are more technology intensive (such as automobiles). More recently, Jaravel (2016) studies the effect of rising inequality on product innovation in the US. He shows that because the income of high-income households grew faster than that of the rest of the population, firms introduced more new products to accommodate the growing demand from wealthy consumers.

The rest of the paper is organized as follows. Section 2 describes our data sources and provides some descriptive statistics. Section 3 explains the econometric model and lays out our empirical strategy. Section 4 presents the baseline results, provides separate evidence on exporters and non-exporters, and discusses the robustness of our estimates. Section 5 discusses a variety of robustness checks. Finally, Section 5 concludes.

\section{$2 \quad$ Data and Descriptive Statistics}

We use two micro-level data sources. The first contains household-level data about the ownership of durable goods to construct a count measure of actual market size. 4 The

\footnotetext{
${ }^{4}$ Working with durable goods ownership rather than household expenditure data has some important advantages but also bears some difficulties. The main advantage is that CHNS' coverage of a relatively broad set of different durable goods allows to construct a market size measure with substantial industry and time variation which can be linked relatively straightforward to different industries in the manufacturing data. Second, the lumpy nature of durable goods creates an interesting variation in ownership profiles across the income distribution which can be exploited to create an exogenous measure of market size. As
} 
second contains firm-level manufacturing data about value added, investments and employment that we used to estimate total factor productivity, our main outcome measure of innovative investments.

\subsection{Market Size}

The household-level ownership data are from the China Health and Nutrition Survey (CHNS). The CHNS was collected in eight waves between 1989 to 2011, and covers a representative sample of Chinese urban and rural households across nine provinces with substantial variation in geography, economic development and public resources. These data are publicly available and are widely used in the literature 5 The CHNS contains information, for a number of durable goods, on how many items of a particular durable good are owned by each household, of which we also know the income and household size. We combine this information with the size of the Chinese population to estimate the total number of items of a particular durable good $j$ held by Chinese consumers in year $t$, denoted by Stock $k_{j, t}^{a c t u a l}$ 6

Figure 1 shows the diffusion patterns of five selected durable goods between 1989 to 2011: bicycles, electric fan, refrigerator, air condition, and car 7 The years not covered by the CHNS are fitted by linear interpolation. The time interval between 1998 and 2007, which we can match to the firm-level data described below, is marked with the dotted vertical lines. Electrical fans were already widespread in the early years, and feature some saturation in more recent years. Saturation is even stronger for bicycles whose stock is decreasing since 2000, likely to be due to their progressive substitution with higherranked transportation vehicles such as motorcycles and cars. There is no saturation for refrigerators, air conditioning and cars. The ownership of these durables is booming during the period of our study.

We use the evolution of the ownership stock to infer the flow of newly purchased goods, our proxy for market size. To calculate such a flow we take into account that the per capita stock of each durable good can change for three reasons: (i) some households acquire the good for the first time (extensive margin); (ii) some households who already own units of the good buy additional units (intensive margin); (iii) some households replace worn out items (replacement demand). Assuming a constant replacement rate $\delta_{j}$ yields the following annual flow of newly purchased goods (actual market size):

$$
M S_{j, t, t+1}^{a c t u a l}=\underbrace{\left[S t o c k_{j, t+1}^{a c t u a l}-S t o c k_{j, t}^{a c t u a l}\right]}_{\text {new purchases }}+\underbrace{\delta_{j} \cdot S t o c k_{j, t}^{a c t u a l}}_{\text {replacement purchases }}
$$

Unfortunately, the CHNS provides no information about when households decide to

a major disadvantage relative to expenditure data, we have no information about the value of different durable goods. Therefore, we can only use the population count of each durable good in the population and need to abstract from value weighted market size measure. See Appendix B.1 for greater detail.

${ }^{5}$ See, among others, Benjamin et al. (2005), Benjamin et al. (2005b), Liu (2008). The survey waves in the CHNS are 1989, 1991, 1993, 1997, 2000, 2004, 2006, 2009 and 2011. To keep a consistent sample, we drop provinces of the three mega cities that were only included in the last wave in 2011 .

${ }^{6}$ The population of China is from the Penn World Tables. More formally, we use the number of items of a specific durable good $j$ in wave $t$ owned by household $h$, rowned $_{h, t}$, and the number of household

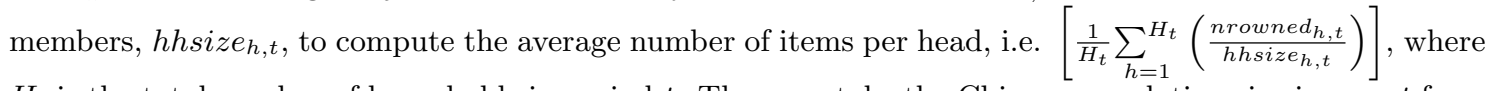
$H_{t}$ is the total number of households in period $t$. Then, we take the Chinese population size in year $t$ from the Penn World Tables 8.1, Feenstra et al. (2015), to get Stock $k_{j, t}^{\text {actual }}$.

7 "Bicycles" are the cumulative ownership of bicycles and tricycles. See Section 2.2 for detail. 
Figure 1: Evolution of Durable Good Stocks

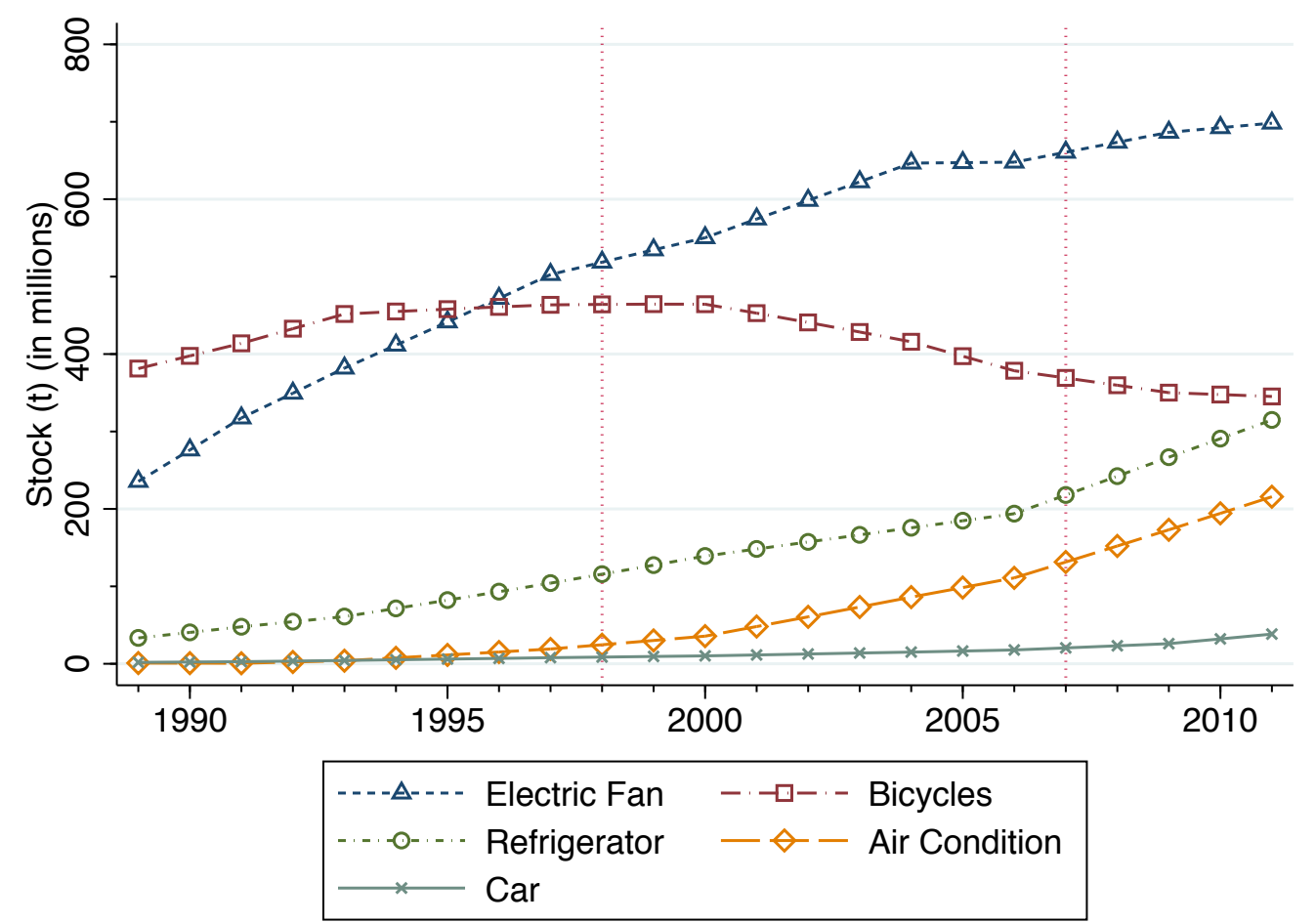

Notes: The figure shows the total items owned (in millions) for each durable good, Stock $k_{j, t}^{a c t u a l}$, i.e. for electric fans, refrigerators, air conditioners and cars. "Bicycles" is the cumulative ownership of bicycles and tricycles. CHNS data 1989 to 2011, years between survey waves linearly interpolated.

scrap existing durable goods. Nor could we find estimates of depreciation of durables for China. We resort to using the depreciation estimates available for the US from the BEA (2003). As shown in Appendix Table A.1, the BEA (2003) offers depreciation estimates for a large variety of different durable goods for the years 1925 to 1995 \& $^{8}$ We use the average over this long period. We check the robustness of the results to using alternative depreciation rates. The results are robust to a large range of depreciation rates. When the estimate of $M S_{j, t, t+1}^{a c t u a l}$ so calculated is smaller than one, we set $M S_{j, t, t+1}^{a c t u a l}$ to one $9^{9}$

Figure 2 displays the evolution of market size for the five durable goods displayed in Figure 1. The electric fan market is stagnant; the market for bicycles is shrinking; finally the markets for refrigerators, air conditioning and cars are growing.

In our regression analysis below, we use market size over a multi-period horizon. More formally, our market size measure is the yearly average over the relevant period (e.g., $k=4$ means a five-year horizon taking into account the stock of goods between $t$ and $t+4)$ :

$$
M S_{j, t, t+k}^{a c t u a l}=\frac{1}{k} \sum_{s=0}^{k-1}\left[M S_{j, t+s, t+s+1}^{a c t u a l}\right] .
$$

${ }^{8}$ The BEA (2003) estimates the length of service lives (in years) for a large variety of durable goods for years 1925 and 1997. By definition, assets are "retired" from the stock at the end of their service lives. Following the BEA (2003), we set $\delta_{j}$ equal to the inverse of the service life of a durable good $j$. This represents the share of the total stock of a durable, which needs to be replaced each year, in order to keep the total stock constant.

${ }^{9}$ While this adjustment is somewhat arbitrary, we prefer this route to eliminating negative observations from the sample, as the latter would cause a major selection problem. In the case of negative growth, we set $M S^{\text {actual }}$ to unity rather than to zero because in the regression analysis below we take the logarithm of $M S^{\text {actual }}$ and this is not defined at zero. To keep the ranking of goods unchanged, this then requires us to set all observations between zero and one to one. Note that this adjustment only concerns two observations of $M S_{j, t, t+1}^{a c t u a l}$ of radios in 2004 and 2005. However, in our baseline regressions these two observations are not included as we are interested in the market size effect over a longer time horizon, i.e. $M S_{j, t, t+4}^{a c t u a l}$. 


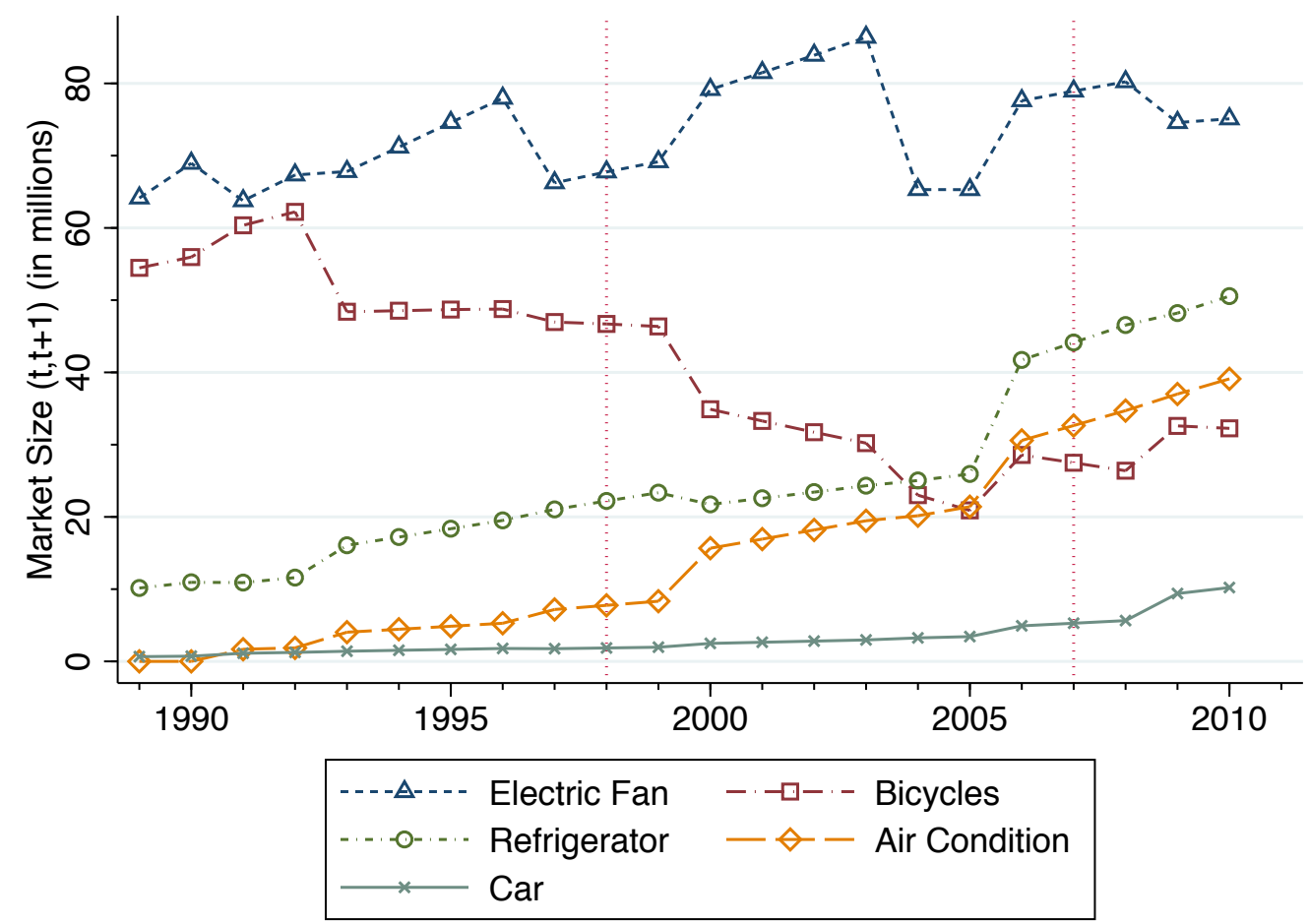

Notes: Actual market size is constructed as explained in the text, i.e. $M S_{j, t, t+1}^{a c t u a l}=$ $\left[S t o c k_{j, t+1}^{a c t u a l}-S t o c k_{j, t}^{a c t u a l}\right]+\delta_{j} \cdot S t o c k_{j, t}^{a c t u a l}$ where estimates for $\delta_{j}$ are taken from the BEA (2003). CHNS data 1989 to 2011.

\subsection{Industrial Production}

We use firm-level data from the Annual Survey of Industrial Production (ASIP) 1998-2007. The survey is conducted by the Chinese government's National Bureau of Statistics (NBS). The ASIP is a census of all non-state firms with more than 5 million RMB in revenue (about $\$ 780$ '000 at the current exchange rate) plus all state-owned firms in manufacturing. The raw data consists of over 150,000 firms in 1998 and grows to over 300'000 firms in 2007. The ASIP covers a wide range of information about the firm's balance sheet, cash-flow and ownership which provides us with a rich set of control variables. This data set has been used extensively in the recent literature 10

We estimate total factor productivity (TFP) at the firm-level using data on value added, the stock of fixed assets, intermediate inputs and employment applying the estimation procedure suggested by Ackerberg, Caves and Frazer (2015) to account for the endogeneity of factor input choices ${ }^{11}$ We take TFP as a proxy for the investment in innovation $\sqrt{12}$ We check the robustness of our results by using labor productivity as a second measure of innovation activities. This is sometimes preferred to TFP in the literature, due to its superior stability (see also Crépon et al. 1998). The most natural measure of innovation however, would be R\&D expenditure. Unfortunately, however, this information

\footnotetext{
${ }^{10} \mathrm{~A}$ detailed description of the data set can be found in Brandt et al. (2011). Other recent papers include, for instance, Feenstra et al. (2014) and Hsieh and Klenow (2009).

${ }^{11}$ We tested both the estimation procedures suggested by Ackerberg, Caves and Frazer (2015) and by Levinsohn and Petrin (2003). All our results are virtually similar when we use one or the other. The estimation of total factor productivity is explained in greater detail in Appendix B.2

${ }^{12}$ Using TFP as a proxy for innovative investments is common in the literature. See among others, Crépon et al. (1998) or Acemoglu et al. (2010).
} 
is not available before the years 2005 to 2007 .

We link each durable good observed in the CHNS to the four digit manufacturing industry producing it as a final household consumption good according to the NBS (2008) description of the Chinese Industry Classification (CIC) system. A limitation of this approach is that it neglects those industries which produce the durable goods as equipment or intermediate inputs (as opposed to final goods) for other industries - this is however quantitatively not very important for the durable goods we consider. We collapse the 22 categories of durable goods available from the CHNS into 16 manufacturing industries, as in some cases different durable goods are produced by firms belonging in the same four-digit manufacturing industry 13

As noted by Feenstra et al. (2011), the NBS data are fairly noisy due to mis-reporting and other sources of measurement error. To minimize measurement error, we follow their procedure. First, we exclude firms with less than 10 employees and those with missing values of key financial variables (i.e. total assets, net value of fixed assets, sales, gross value). Second, we drop observations for which basic accounting identities are not correct ${ }^{14}$ Finally, we drop firms with missing variables or negative values for variables used to calculate our productivity measure (value added, real capital stock and intermediate inputs) ${ }^{15}$ We end up with a final sample of 25’394 firm observations in 16 durable good industries over the years 1998-2007.

\section{Empirical Strategy}

\subsection{Econometric Model}

To study the effect of market size on innovation we consider the following regression model

$$
\ln Y_{i, j, t}=\alpha\left(\ln M S_{j, t, t+4}^{a c t u a l}\right)+\mathbf{X}_{i, j, t}^{\prime} \beta+\psi H H I_{j, t}+\eta_{j}+\lambda_{t}+\epsilon_{i, j, t},
$$

where $i$ denotes a firm, $j$ an industry (durable good) and $t$ the time. The main goal is to estimate the effect of the future market size at the industry level, $M S_{j, t, t+4}^{a c t u a l}$, on the firm-level measure of innovation activity, $Y_{i, j, t} . M S_{j, t, t+4}^{a c t u a l}$ measures the annual average change in the total number of items of a durable good $j$ between $t$ and $t+4$ adjusted for depreciation, as discussed above. The five-year window benchmark is similar as in Acemoglu and Linn (2004), as this is a plausible time horizon to determine firms' investments in innovation. Our main outcome variable is TFP, a proxy for the firm-level investment in technology adoption. Moreover, we perform a robustness analysis using alternative proxies for innovation such as labor productivity

\footnotetext{
${ }^{13}$ Since color TVs and DVD players are produced by the same four-digit manufacturing industries, we created a new ownership variable for home video appliances which is simply the cumulative ownership of those two goods irrespectively whether this is a color TV or a DVD player. We proceed in a similar fashion in the case of the kitchen appliance industry as the cumulative of microwaves, rice cookers and pressure cookers and in the case of the cycle industry being the cumulative of bicycles and tricycles. The exact list of durable goods and matched industries can be found in Table A.2 in the data appendix.

${ }^{14}$ In particular, we drop firms if (a) its total assets are smaller than its current assets, (b) its total assets are smaller than its total fixed assets, (c) its total assets are smaller than the net value of its fixed assets, (d) its sales are below 5 million RMB, (e) its interest payments are negative.

${ }^{15}$ We also employ their procedure to link restructured firms over time, cf. the online appendix of Brandt et al. (2011) for more details.

${ }^{16}$ Depending on the length of the time window, we have to exclude certain industries from the analysis, e.g. since satellite dish ownership is only available from 2006 onwards, we have to exclude this industry in our baseline analysis with the five-year time window.
} 
In all specifications, we include industry fixed effects, $\eta_{j}$, to account for industryspecific innovation intensities (e.g., the car industry is inherently more technology-intensive than the bicycle industry). Time fixed effects, $\lambda_{t}$, absorb aggregate shocks (e.g., business cycle fluctuations, China joining the WTO, etc.). The vector $\mathbf{X}_{i, j, t}$ controls for unobserved firm-level heterogeneity to ensure that estimates are not biased by omitted determinants of investment in innovation ${ }^{17}$ First, we control for the firm size using the log number of workers as suggested in the literature. This is important since firm size could be a determinant of its propensity to invest in innovation. Second, we control for the ownership structure of firms that can be important to determine firms' financial structure and innovativeness 18 Specifically, we take privately owned firms as the reference group and introduce three dummy variables for whether a firm is foreign, state or collective owned. Third, we add a dummy for firms that are older than six years (the median in our sample) in order to control for the age of firms ${ }^{19}$ Further, we include a dummy for firms located in coastal provinces, as firms in the booming coastal regions might be overrepresented in some sectors. Finally, to control for different intensities of market competition across sectors, we introduce the Hirschmann-Herfindahl index, which is defined as the sum of squared market shares of all firms within the sector ${ }^{20}$ Summary statistics on all variables are listed in Table A.3.

The coefficient of interest, $\alpha$, captures the effect of future market size on a firm's investment in technology. The theory of directed technical change outlined in the introduction predicts that $\alpha$ should be positive. As both our dependent variable and market size are in logs, the coefficient can be interpreted as an elasticity.

\subsection{Endogeneity and Potential Market Size}

The most important econometric issue is the potential endogeneity of the market size measure. Firms' investments in technology adoption can influence the future stream of durable good purchases by affecting the prices or the quality of durable goods. For instance, process innovation reduces production costs, whereas product innovation makes available better varieties for which consumers are willing to pay more. Through these channels, a higher intensity of innovation in an industry may increase the industry's future market size. Due to the endogeneity problem, OLS regressions may yield inconsistent estimates of the parameter $\alpha$. To address this problem, we instrument $M S_{j, t, t+4}^{a c t u a l}$ with a measure of potential market size, $M S_{j, t, t+4}^{\text {potential }}$ which is independent of supply shocks affecting the prices or the quality of durable goods. The identification strategy is in close spirit to the one employed by Acemoglu and Linn (2004). They use demographic variables to predict the evolution of market size for different drugs, taking into account the usage pattern across age groups in the population. Intuitively, a fast-aging population implies that the market for drugs used to treat patients suffering from the Alzheimer syndrome

\footnotetext{
${ }^{17}$ See Crépon et al. (1998) and Mairesse and Mohnen (2010) for a review of firm-level innovation determinants.

${ }^{18}$ See for example Song et al. (2011).

${ }^{19}$ Arnold and Hussinger (2005) for example argue that due to possible correlation between size and age of a firm employing a dummy instead of the absolute age seems to be the correct estimation approach.

${ }^{20}$ Studies that specifically employ the HHI are for example Cotterill (1986), Farrell and Shapiro (1990) and Farrell and Shapiro (1990). We define the HHI for industry $j$ at time $t$ as the sum of squared market shares (in value added) of all firms operating within this sector at time $t$. Since we calculate market shares in percentage terms, (between 0 and 100), the HHI lies in the range between 0 and 10000 . We are aware of the fact that the border of markets is less clear for globally operating firms. However, we consider the HHI as the first best measure to capture market competition within the firm's primary (home) market.
} 
grows faster than that for drugs used to treat child obesity. Their demography-based measure of potential market size is exogenous to innovative investments, and is therefore a valid instrument. Our approach is similar to the one of Acemoglu and Linn (2004). We assume that the market size of each durable good depends on the evolution of income growth and the income distribution, given the diffusion curve associated with each durable good. In particular, we assume that households in different income brackets purchase each durable good with a given probability that we estimate. Then, we construct a measure of potential market size for each durable good that depends only on macroeconomic variables (e.g. the growth of household income) and not on supply-driven shocks. Under the assumption that macroeconomic changes are exogenous to firms (and industries) investing in new technologies, market potential is a valid instrument for the actual market size. Note that the exclusion restriction would be violated if the innovative investments of firms producing a particular good could affect the future aggregate economic growth (or income distribution) in China. However, this is unlikely to be the case since we focus on narrowly defined industries producing small shares of the total income of China ${ }^{21}$

More formally, we start from breaking down the Chinese population into four groups using fixed income thresholds in constant 2011 Yuan 22 Figure 3 shows the evolution of the population shares of the four income groups over the survey period. The population share of the two poorer groups falls dramatically over time, especially between 1998 (63 $\%$ ) and 2007 (40\%). Conversely, the share of high income households increases from $12 \%$ in 1998 to $37 \%$ in 2007. Together, the two upper income groups account to $60 \%$ in 2007.

Next, we construct the usage intensities, $u_{j, g, t}$, by estimating the number of items per capita of each durable good $j$ owned by agents in income group $g$ at time $t$. Appendix Table A.5 presents these usage profiles for the CHNS year 1997, the last year before our firm data start (1998-2007). As expected, the usage profiles are upward sloping for all durable goods. Yet, there are considerable differences between durable goods.

For cars, for instance, ownership increases most dramatically (3.5 fold) when switching from the high middle group to the highest income group. For motorcycles, in contrast, the largest increase is from the lowest income group to the low middle income group (an almost 2 fold increase) whereas ownership from the group high middle to high increases much less (1.4 fold). These differences across usage patterns are the crux of our identification.

Finally, we construct our measure of potential market size as

$$
M S_{j, t, t+1}^{\text {potential }}=\left(S t o c k_{j, t+1}^{\text {potential }}-S t o c k_{j, t}^{p o t e n t i a l}\right)+\delta_{j} \cdot \text { Stock }_{j, t}^{\text {potential }},
$$

where

$$
\text { Stock }_{j, t}^{\text {potential }}=\sum_{g} \bar{u}_{j, g} \cdot i_{g, t}
$$

and $i_{g, t}$ is the number of people in income group $g$ in year $t$ and $\bar{u}_{j, g}=u_{j, g, t=1997}$ is the number of item of durable good $j$ owned per head in income group $g$ in the year 1997. Note that the choice of the base year to compute the usage intensities is to some

\footnotetext{
${ }^{21}$ Also, although investments in innovation are correlated across industries, recall that we control for time dummies in our regressions, so the identification comes from deviations from common trends in TFP.

${ }^{22}$ Households are grouped into four income groups according their (annual) household income per capita in constant 2011 Yuan and quartile thresholds of the pooled 1997-2006 income distribution: low income (below 2'293 Yuan), lower middle income (2'294- 4'539 Yuan), upper middle income (4'540 - 8'136 Yuan), high income (8'137 Yuan or more). In constant 2011 USD (PPP adjusted), this corresponds roughly to: low income, USD 654, low middle income, USD 655 -USD 1294, high middle income, USD 1295 - USD 2320, high income, USD 2321 or more.
} 


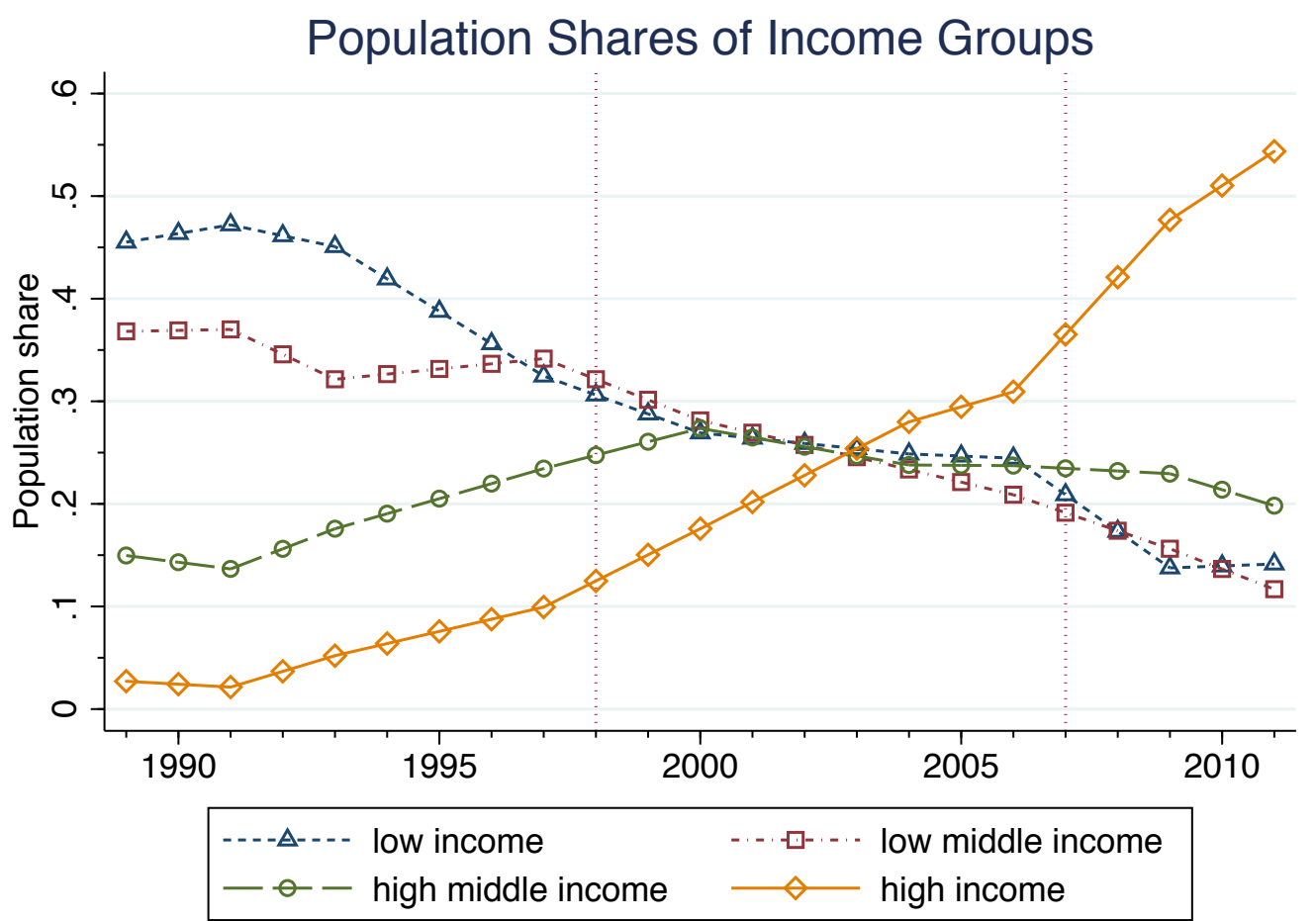

Notes: Households are grouped into four income groups according their household income per capita in constant in constant 2011 Yuan and quartile thresholds of the pooled 1997-2006 income distribution: low income (below 2'293 Yuan), lower middle income (2'294- 4'539 Yuan), upper middle income (4'540 - 8'136 Yuan), high income (8'137 Yuan or more). CHNS data 1989 to 2011.

extent arbitrary ${ }^{23}$ Our measure exploits the fact that there are significant differences in the ownership of durable goods across income groups. As the economy grows, more households enter higher income groups and start purchasing durable goods. This process affects asymmetrically the demand of different durable goods. As Table A.5 shows, durable goods whose diffusion increases the most across low income groups (such as electric fans or motorcycles), diffuse faster at an earlier stage of development. In contrast, for goods such as cars, the diffusion is fastest as more households climb up into the highest income group. Note that there are differences between $M S_{j, t, t+1}^{\text {potential }}$ and $M S_{j, t, t+1}^{\text {actual }}$. Part of these differences reflect changes (typically, increases) in the usage intensities that apply to all income groups. Beerli (2010), shows that a large part of these is explained by falls in prices ${ }^{24}$ Price-driven changes in demand, in turn, are likely to be related to supply-side shocks, e.g. technical progress reducing the production cost. Our measure of potential market size abstracts from such changes and is therefore immune from supply-side shocks. In other words, changes in prices and quality of durable goods which may result from

\footnotetext{
${ }^{23}$ In principle, we could measure the usage intensity in each income group also in earlier CHNS waves allowing for a larger time lag before our analysis period starts, e.g. in 1993. This creates measurement problem, however, since only few individuals were in the higher income group and, thus, the usage intensity of these groups cannot be measured with similar accuracy. All our baseline results are qualitatively similar if we usage 1993 as the base to measure usage intensity. We use 1997 the measure the usage intensity for all goods but cellphones and satellite dishes which were included in the CHNS household survey from 2004 and 2006 respectively. We use those first available years in the CHNS for those goods. All regression results are robust to omitting both industries from the sample.

${ }^{24}$ An example is color TVs. Beerli (2010) shows that the rise in income levels can only explain about one third of the total increase in color TV ownership for an average household between 1989 and 2006.
} 
investments in technology adoption, cannot cause over-time variation in $M S_{j, t, t+1}^{\text {potential }}{ }^{25}$ In fact, Appendix Figure A.1 reveals that income-specific usage rates are indeed changing due to differential price dynamics. Moreover, the variation across industries shows the differential speed of technological progress across industries.

\section{Results}

This section presents our empirical results. We start by looking at OLS and IV estimates using log firm-specific TFP as the dependent variable. We then address the potential concern that the domestic market may be of central importance for non-exporting firms, but much less relevant for exporters, where market size is determined by demand on the world market. We then address the concern that industries might be very different with respect to R\&D intensity. Next, we show that using labor productivity rather than TFP as an alternative left-hand-side variable does not change the general patterns of our results. Finally, we provide industry-regressions, which yield results comparable to those of the firm-level regression of our basic specification.

\subsection{OLS and IV Regressions}

Table 1 provides results from regressions, all of which include time- and industry-fixed effects. Standard errors are clustered at the firm level ${ }^{26}$ We do not report the estimated coefficients for the full set of control variables, which are deferred to Table A.6 in the Appendix. Column (1) yields the estimate of $\alpha$ in the baseline OLS regression without controls. The coefficient is positive and highly significant. Increasing the future market size by one percent raises firms' TFP by $0.24 \%$. However, part of the effect could be spuriously driven by omitted time-varying firm characteristics. We then control for a large number of firm-level variables including size, ownership, age, and location 27 We also control for the Hirschmann-Herfindahl index for market competition at the industry level. Controlling for these firm and industry characteristics causes a reduction in the size of the estimated coefficient, which falls to $0.07 \%$, see column (2) of Table 1

Next, we run two-stage least squares (2SLS) regressions to account for the endogeneity of the actual market size measure. We use our measure of "potential market size" as an instrument for the actual market size. As explained in Section 3.2, potential market size is exclusively driven by future changes in the income distribution. This measure is orthogonal to price or quality changes that could affect changes in ownership patterns and

\footnotetext{
${ }^{25}$ We are particularly concerned that innovation activities of firms in year $t$ may affect future usage intensities, i.e. $u_{j, g, t+k}$ with $k>0$, and through this the expected market size in upcoming years, $M S_{j, t, t+k}^{a c t u a l}$. Thus, a less conservative notion of potential market size would allow to use lagged usage intensities for each given year. Yet, as innovation activities of firms show considerable serial correlation, we take the most conservative approach possible and fix usage intensities to one specific year.

${ }^{26}$ In Appendix Table A.6 (Column (3) and (6)) we also consider an alternative clustering strategy allowing for correlation across two dimensions (two-way clustering à la Cameron et al., 2011): (i) correlation within firms across years, (ii) correlation within sector within a given year (sector $\times$ year clusters). This leads to an insignificant estimate in the OLS case (column (3)) but does not alter the significance of the IV estimate (column (6)). As two-way clustering never affects the significance of our estimates we only present standard errors clustered at the firm level in the main part of the paper. An even more demanding strategy would be to cluster standard errors at the industry level. However, this is not possible with our data, since the number of clusters would in this case be too small (see Angrist and Pischke (2009) for a discussion of the problems arising with too few clusters). Following Angrist and Pischke (2009), we check the validity of our results by collapsing observations on the industry level.

${ }^{27}$ See Crépon et al. (1998) and Mairesse and Mohnen (2010) for a review of firm-level innovation determinants.
} 
Table 1: Effect of Market Size on Log Total Factor Productivity

Dependent variable: Log Total Factor Productivity

\begin{tabular}{|c|c|c|c|c|}
\hline \multirow[t]{2}{*}{ Method } & \multicolumn{2}{|c|}{$\overline{\mathrm{OLLS}}$} & \multicolumn{2}{|c|}{ IV } \\
\hline & $(1)$ & $(2)$ & $(3)$ & $(4)$ \\
\hline \multirow{2}{*}{$\ln M S_{j, t, t+4}^{a c t u a l}$} & 0.116 & 0.070 & 0.472 & 0.349 \\
\hline & $(0.039)^{* * *}$ & $(0.038)^{*}$ & $(0.064)^{* * *}$ & $(0.064)^{* * *}$ \\
\hline R-squared & 0.089 & 0.140 & 0.083 & 0.137 \\
\hline Observations & 25394 & 25394 & 25394 & 25394 \\
\hline $\begin{array}{l}\text { Year and Industry FE } \\
\text { Firm controls }\end{array}$ & $\sqrt{ }$ & $\begin{array}{l}\sqrt{ } \\
\sqrt{ }\end{array}$ & $\sqrt{ }$ & $\begin{array}{l}\sqrt{ } \\
\sqrt{ }\end{array}$ \\
\hline \multicolumn{5}{|c|}{$\begin{array}{l}\text { Notes: } * * * \mathrm{p}<0.01,{ }^{* *} \mathrm{p}<0.05,{ }^{*} \mathrm{p}<0.1 \text { denote significance on the } 10 \%, 5 \% \\
\text { and } 1 \% \text { level, respectively. Standard errors are clustered at the firm level. } \\
\text { All columns include year and industry fixed effects. Columns }(2) \text { and }(4) \text { in- } \\
\text { clude a set of firm- and industry-level controls (the log of number of workers, } \\
\text { age (measured by a dummy), a dummy for collective, state and foreign own- } \\
\text { ership, coastal location, respectively and the Hirschmann-Herfindahl index). } \\
\ln M S_{j, t, t+4}^{\text {actual }} \text { is instrumented with } \ln M S_{j, t, t+4}^{\text {potential }} \text {. }\end{array}$} \\
\hline
\end{tabular}

cause an endogeneity problem. Formally, for this to be a valid instrument, it must be correlated with the actual market size and be uncorrelated with the error term.

The results of the 2SLS regressions are reported in columns (3) and (4) of Table 1. The effect of market size on firms' TFP is larger than in the OLS specification. Column (3) repeats the regression of column (1), where we control only for industry and time fixed effects. The estimated coefficient is positive and highly significant. Controlling for the firm- and industry level characteristics listed above yields a lower coefficient. However, it remains large and highly significant. The estimate in column (4) - the analogue of the OLS regression in column (2) - implies that a one percent exogenous increase in market size leads to an increase in TFP of $0.35 \%$. This is a large effect (almost five times as large as the OLS estimate), suggesting the importance of profit incentives as a driver of firms' innovation activities.

Table 2 presents the results of the first stage regressions. Columns (1)-(2) show the results corresponding to columns (4)-(5) in Table 1. Potential market size is significantly correlated with the actual measure of market size and suggests that a one percent change in potential market size (driven only by income changes) leads to a change in actual market size by nearly $2.7 \%$. The last row of Table 2 shows that the F-statistic of the excluded instrument is well above the conventional threshold of 1028

${ }^{28}$ The high F-statistics result from our strategy to cluster the standard errors are the firm level. Appendix Table A.6 (column (6) and Table6 show that the F-statistics is substantially reduced when we use 2-way clustering or run regressions on the industry-level (using robust standard errors). In any case, the Fstatistic remains above the critical level of 10 identified by Staiger and Stock (1997). 
Table 2: First Stage Regression

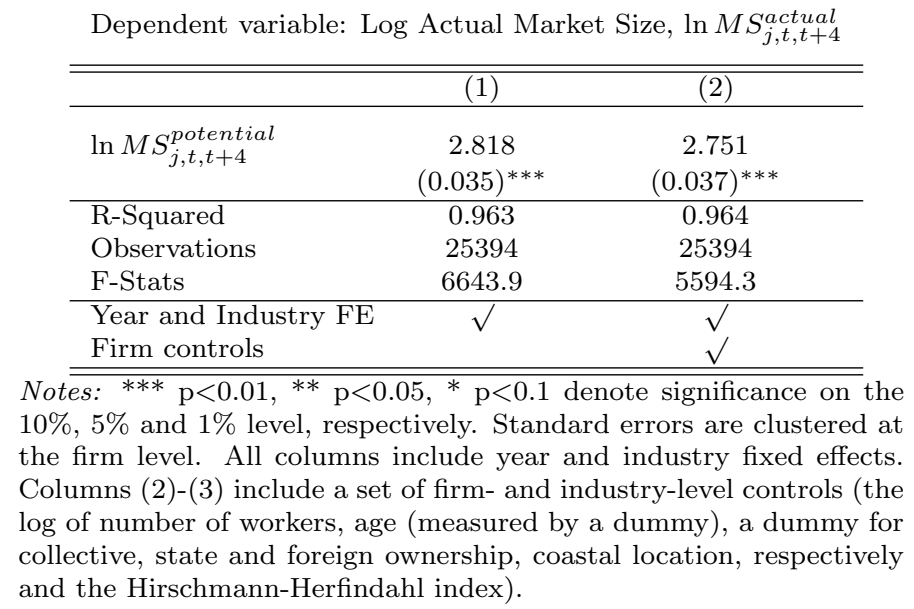

Finally, Figure 4 summarizes our empirical findings by a convenient visualization. The Figure plots for a subsample of the durable good industries, which are available over the entire time horizon of our data, their change in log productivity between 1998 and 2007, $\left(\ln T F P_{j,{ }^{\prime} 07}-\ln T F P_{j,{ }^{\prime} 98}\right)$, against their change in potential market size, $\left(\ln M S_{j,{ }^{\prime} 07,{ }^{\prime} 11}^{\text {potental }}\right.$ $\left.\ln M S_{j,{ }^{\prime} 98,{ }^{\prime} 04}^{\text {potential }}\right)^{29}$ Looking at the change in productivity and potential market size allows differentiating out level differences between industries, as we do when we run regressions using industry fixed effects. Since we empirically stress the importance of the market size effect for firms' innovation behavior, we expect TFP to increase faster for firms within industries that are subject to stronger growth in demand over the sample period. The Figure shows that there is indeed a positive, unconditional correlation: productivity grew more in industries with larger income-growth driven shifts in market size, e.g. among manufacturers of cars, air conditions or computers, whereas the increase in productivity is weaker (but still positive) in industries with more modest demand change, e.g. manufacturers of bicycles, electric fans or sewing machines.

\subsection{Domestic Market Size and Firm's Export Status}

An obvious concern with the above analysis is that the size of the domestic market might of very different importance for exporting versus non-exporting firms. For exporters, investment in new technologies may be driven by foreign demand as well. To address this issue, we exploit the available information in our manufacturing data on firms' export activity in several ways. First, we simply include a dummy capturing whether a firm is engaged in export activities. Second, we can construct measures of a firm's indirect exposure to the export market through it's suppliers or through similar firm's in the same sector. Third, we can simply analyse whether the effect of domestic demand is different for firms with levels of engagement in the foreign market (exporting/not exporting in a given year, never exporting).

Table A.3 shows that $46 \%$ of all firms in the durable good industries considered in our study engage in export activities. The export exposure varies considerably across industries. For instance, the average fraction of sales going to foreign markets is high for camera and radio manufacturers ( $74 \%$ and $68 \%$, respectively), while it is fairly low for car,

\footnotetext{
${ }^{29}$ Note that cellphones, satellite dishes and radios are excluded from this Figure as we do not have data for the full time horizons for these industries. One concern could be that single sectors significantly drive the results. In table A.7 we show that our favoured specification including all controls for non-exporters is robust to omitting any single sector from the sample.
} 
Figure 4: Change in log productivity versus change in potential market size between 1998 and 2007 in durable good producing industries

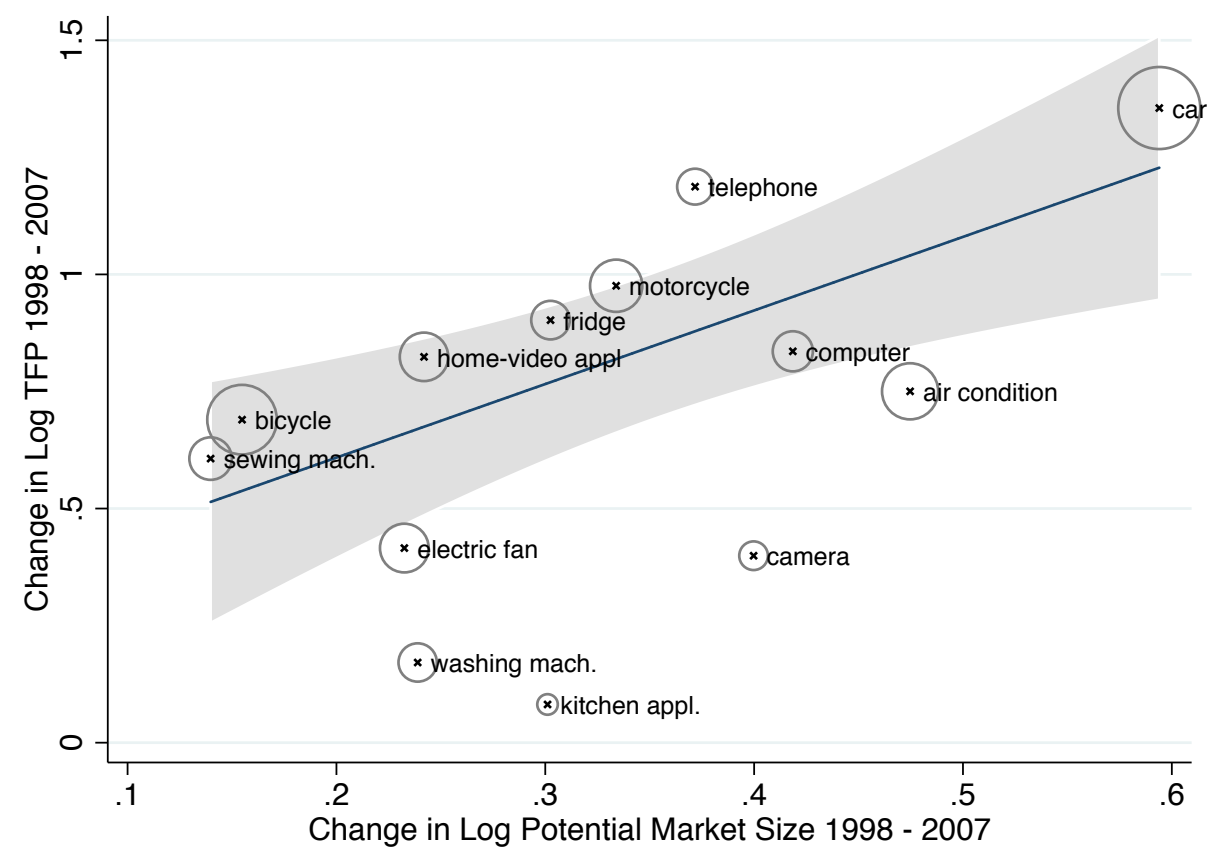

Notes: The figure plots the change in the average log TFP in durable good industries between 1998 and 2007 on the average change in log market size in the same period. The straight line (shaded area) represents the linear fit (confidence interval) from a regression of the form $\Delta_{1998}^{2007} \ln T F P_{j}=\alpha+\underset{(0.44)}{1.57} \Delta_{1998,2002}^{2007,2011} \ln M S_{j}^{\text {potential }}+\epsilon_{j}$ in which we used the number of firms in 1998 as weights. Note that cellphones, satellite dishes and radios are excluded as we do not have data for the full time horizons for these industries.

air condition or motorcycle manufacturers $(19 \%, 37 \%$ and $38 \%$, respectively) 30 In Table 3 we show that our previous results are robust to controlling for export behavior. Column (1) is the same as column (4) in Table 1. In column (2), we include among the regressors an indicator for whether a firm has positive export sales. As expected, we find that exporters are on average more productive than non-exporters (although not significantly so in our sample). The inclusion of this dummy leaves the coefficient of interested practically unchanged. In column (3) and (4), we include two different proxies for a firm's exposure to the world market at the industry level. Both proxies are motivated by the idea that a firm could be strongly affected by the world market (rather than the domestic market) even though it is not exporting itself. In column (3), we add for each durable good industry and year the share of exporters among its intermediate good producers based on the Chinese Input-Output Table 2002. In column (4) instead, we include the share of exporters in the same durable good industry. Including these proxies for exposure to the world market increases the demand effect slightly.

In the next two column (5) and (6), the sample is split into firms which report positive exports and those that currently do not export. Lastly, column (7) constrains the sample to those firms which never report positive exports between 1998-2007. The three columns tell a clear story: The expansion of the domestic market does not matter for globally active firms, their market size effect is zero (in column (5)). On the other hand, domestic demand has a strong effect on the productivity of firms that operate sometimes (column (6) or exclusively in it (column (7)) ${ }^{31}$

\footnotetext{
${ }^{30}$ Detailed descriptive statistics on the industry level are shown in Table A.4

${ }^{31}$ In fact, Figure A.2 shows that the distribution of firms ranked by their export share relative to total sales is highly bimodal. Thus, firms seem to serve either only the domestic or exclusively the foreign market, which explains the insignificance of the market size effect for exporters.
} 
Table 3: Robustness analysis: controlling for export behavior

Dependent variable: Log Total Factor Productivity

\begin{tabular}{|c|c|c|c|c|c|c|c|}
\hline \multirow[t]{3}{*}{ Sample } & & & & & \multicolumn{2}{|c|}{ Currently exporting } & \multirow{3}{*}{$\begin{array}{c}\begin{array}{c}\text { Never } \\
\text { exporting }\end{array} \\
(7)\end{array}$} \\
\hline & \multicolumn{4}{|c|}{ All } & yes & no & \\
\hline & $(1)$ & $(2)$ & $(3)$ & $(4)$ & $(5)$ & (6) & \\
\hline $\ln M S_{j, t, t+4}^{a c t u a l}$ & $\begin{array}{c}0.349 \\
(0.064)^{* * *}\end{array}$ & $\begin{array}{c}0.348 \\
(0.065)^{* * *}\end{array}$ & $\begin{array}{c}0.381 \\
(0.078)^{* * *}\end{array}$ & $\begin{array}{c}0.432 \\
(0.086)^{* * *}\end{array}$ & $\begin{array}{l}-0.026 \\
(0.102)\end{array}$ & $\begin{array}{c}0.473 \\
(0.083)^{* * *}\end{array}$ & $\begin{array}{c}0.534 \\
(0.094)^{* * *}\end{array}$ \\
\hline $1\left(\right.$ export $\left._{i, t}=1\right)$ & & $\begin{array}{c}0.022 \\
(0.021)\end{array}$ & & & & & \\
\hline$(\text { Share exporters upstream })_{j, t}$ & & & $\begin{array}{l}-1.650 \\
(1.443)\end{array}$ & & & & \\
\hline$(\text { Share exporters) })_{j, t}$ & & & & $\begin{array}{c}-0.523 \\
(0.232)^{* *}\end{array}$ & & & \\
\hline R-squared & 0.137 & 0.137 & 0.136 & 0.135 & 0.199 & 0.122 & 0.127 \\
\hline Observations & 25394 & 25394 & 25394 & 25394 & 11700 & 13694 & 10872 \\
\hline $\begin{array}{l}\text { Year and Industry FE } \\
\text { Firm controls }\end{array}$ & $\sqrt{ }$ & $\begin{array}{l}\sqrt{ } \\
\sqrt{ }\end{array}$ & $\sqrt{ }$ & $\begin{array}{l}\sqrt{ } \\
\sqrt{ }\end{array}$ & $\begin{array}{l}\sqrt{ } \\
\sqrt{ }\end{array}$ & $\begin{array}{l}\sqrt{ } \\
\sqrt{ }\end{array}$ & $\begin{array}{l}\sqrt{ } \\
\sqrt{ }\end{array}$ \\
\hline
\end{tabular}

Notes: ${ }^{* * *} \mathrm{p}<0.01,{ }^{* *} \mathrm{p}<0.05,{ }^{*} \mathrm{p}<0.1$ denote significance on the $10 \%, 5 \%$ and $1 \%$ level, respectively. Standard errors are clustered at the firm level. All columns include year and industry fixed effects and firm- and industrylevel controls (the log of number of workers, age (measured by a dummy), a dummy for collective, state and foreign ownership, coastal location, respectively and the Hirschmann-Herfindahl index).

\subsection{Accounting for Industry-specific R\&D Intensity}

Another potential source of bias could be global technology shocks which affect differentially the propensity of firms to innovate in different industries as some industries might be more strongly affected by new technologies (for instance, the rise of automation technology, see Autor et al. 2003). 32

To address this concern, we include as additional regressor different measures of technical advancement and innovative activity, using industry-specific information from countries whose firms operate at the technological frontier. First, we include an index measuring the change in TFP since 1987 in US durable good manufacturing industries from the NBER-CES Manufacturing data base. This database provides information on output, employment, and other production relevant variables for four digit US manufacturing industries since 1958 on an annual basis. We use a crosswalk between Chinese and US industries to calculate the yearly TFP index for each durable good industry and year 1998-2007.

As a second data set, we use two more direct measures of technical advancement reported by Swiss firms in the KOF Innovation Survey. This survey covers a representative sample of Swiss firms in the manufacturing sector in the years 1996, 1999, 2002, 2005 and 2008. Again we use a crosswalk to map NACE Rev 1 codes from Swiss industries to our Chinese durable good industries. We linearly interpolate missing years and calculate for each durable good industry and year between 1998-2007 the share of Swiss firms reporting having introduced process or product innovation to their markets. The second measures the share of firms reporting a high technological potential available worldwide which could be used to introduce new products to their market. As the overlap between Swiss and Chinese manufacturing sectors is not perfect, we cannot construct these measures for the full sample of sectors and years 33

Table 4 presents the results. In all specifications, we include the share of exporters

\footnotetext{
${ }^{32}$ In a recent survey of the literature, Draca et al. (2006) show that there was a considerable impact of ICT availability on productivity. Additionally, Bloom et al. (2012) show the effect of IT on productivity was differential even within industries depending on whether firms were US- or non-US-multinationals.

${ }^{33}$ Note that we impute missing information for bicycles and motorcycles industries on the 4-digit industry level in the KOF Innovation Survey with data from the 3-digit level of those industries.
} 
in an industry to control for effects for demand effects from the overseas market similar as in Table 3 Column (4). In column (1), we include for each durable good sector and year an the corresponding TFP in the same sector in the US taken from the NBER-CES Manufacturing Database 34 Including either the contemporaneous TFP index (in column (1)) or its 5-year lag (in column (2)) only increases the estimated coefficient of market size slightly in comparison to the same estimate in Table 3 (Column (4)).

As an alternative way of measuring technical advancement across industries which Chinese firms could benefit from, we use a survey measure of technological opportunities reported by Swiss firms in the KOF Innovation Survey (2012) mentioned above. In this survey, firms are asked to assess the worldwide availability of technological know-how in private and public hands which could be used to generate marketable new products. We calculate the share of firms in an industry reporting high technological potential (a 4 or 5 on a 5-point Likert scale) and include it in column (3).

In column (4), we include an even more direct measure for technological advancement: The share Swiss firms in an industry reporting to have introduced new product or process innovations to their relevant market during the last 2 years. Including any of these two measures produces a slightly smaller estimate for market size (in column (3)) or a similar one (in column (4)). As the sample of firms in the KOF Innovation Survey data does not perfectly cover all Chinese durable good industries in all years, the number matched industry-year observations is a bit smaller than otherwise. This need to be taken into consideration when interpreting these effects.

As a last check, we include for each 3-digit sector in our sample a separate time trend. This is a very demanding specification since our 16 durable good industries fall into only 10 separate 3 -digit industries, each of which is allowed to have a separate time trend 35 Thus, this specification only identifies our coefficient of interest from the deviations of a long-run trend that our income-growth driven market size measure produces. Including these trends increases the market size coefficient to some degree (but also the standard error), but leaves it significant at the $5 \%$ level.

Table 4: Robustness analysis: controlling for technology shocks

\begin{tabular}{|c|c|c|c|c|c|}
\hline \multirow{2}{*}{$\ln M S_{j, t, t+4}^{a c t u a l}$} & 0.463 & 0.468 & 0.376 & 0.464 & 0.683 \\
\hline & $(0.091)^{* * *}$ & $(0.091)^{* * *}$ & $(0.086)^{* * *}$ & $(0.092)^{* * *}$ & $(0.303)^{* *}$ \\
\hline R-squared & 0.136 & 0.136 & 0.133 & 0.131 & 0.140 \\
\hline Observations & 25394 & 25394 & 24755 & 24755 & 25394 \\
\hline US NBER-CES Manuf.: TFP index & $\sqrt{ }$ & & & & \\
\hline US NBER-CES Manuf.: TFP index (5 year lag) & & $\sqrt{ }$ & & & \\
\hline Swiss firm survey: High tech. potential & & & $\sqrt{ }$ & & \\
\hline Swiss firm survey: Share innovators & & & & $\sqrt{ }$ & \\
\hline Sector-specific trends & & & & & $\sqrt{ }$ \\
\hline
\end{tabular}

\footnotetext{
${ }^{34}$ This measure indicates an industries TFP level in a given year relative to its level in 1987.

${ }^{35}$ This includes a separate time trend for manufacturers of air conditions, bicycles, cameras, cars, computers, motorcycles, radios, satellite dishes, sewing machines, telephones and washing machines. The remaining six industries belong to 3 different 3-digit sectors: Manufacturers of air conditioners, electric fans, refrigerators and kitchen appliances belong to the same 3-digit industry. Similarly, producers of cellphones and telephones and producers of home video appliances and radios, respectively.
} 


\subsection{Using Labor Productivity instead of TFP}

To further check the robustness of our results, we repeat our empirical analysis using (the log of) labor productivity as an alternative dependent variable. While labor productivity may increase due to capital deepening, rather than investment in innovation, it has the advantage of being a less noisy measure than TFP. Labor productivity is computed as the value added per employee.

Table 5 displays the results. All regressions include the full set of control variables used in Table 1. Column (1) shows the result of the OLS regression - the coefficient of market size is now positive and highly significant, contrary to column (2) in Table 1. Column (2) shows the 2SLS estimate of the market size coefficient using the same controls. The effect is again positive and significant. An increase in market size by one percent yields an increase of $0.46 \%$ in firm's labor productivity. Again, the 2SLS estimates are larger than the corresponding OLS estimate. In Column (3), we include the share of exporters in a sector as control and in Column (4) we add the TFP index from the NBER-CES manufacturing data base. As with TFP as outcome variable shown above, the market size estimate remains highly significant and even becomes slightly larger. This shows that the previous results are robust to the inclusion of controls for export demand and supply-side drivers of technical change (as discussed in Section 4.2).

Table 5: Robustness analysis: labor productivity

Dependent variable: Log Labor Productivity

\begin{tabular}{|c|c|c|c|c|}
\hline \multirow[t]{2}{*}{ Method } & \multirow{2}{*}{$\begin{array}{c}\text { OLS } \\
(1) \\
\end{array}$} & \multicolumn{3}{|c|}{$\overline{\mathrm{IV}}$} \\
\hline & & $(2)$ & $(3)$ & $(4)$ \\
\hline \multirow{2}{*}{$\ln M S_{j, t, t+4}^{a c t u a l}$} & 0.199 & 0.459 & 0.587 & 0.501 \\
\hline & $(0.041)^{* * *}$ & $(0.068)^{* * *}$ & $(0.092)^{* * *}$ & $(0.088)^{* * *}$ \\
\hline R-squared & 0.143 & 0.141 & 0.139 & 0.142 \\
\hline Observations & 25394 & 25394 & 25394 & 25394 \\
\hline Year and Industry FE & $\sqrt{ }$ & $\sqrt{ }$ & $\sqrt{ }$ & $\sqrt{ }$ \\
\hline Firm controls & $\sqrt{ }$ & $\sqrt{ }$ & $\sqrt{ }$ & $\sqrt{ }$ \\
\hline Export control & & & $\sqrt{ }$ & $\sqrt{ }$ \\
\hline Technology control & & & & $\sqrt{ }$ \\
\hline $\begin{array}{l}\text { tes: }{ }^{* * *} \mathrm{p}<0.01,{ }^{* *} \mathrm{p}< \\
\text { level, respectively. Stan } \\
\text { lude year and industry fi } \\
\text { number of workers, age } \\
\text { foreign ownership, coast } \\
\text { ex). }\end{array}$ & $\begin{array}{l}05, * \mathrm{p}<0 . \\
\text { ard errors } \\
\text { d effects ar } \\
\text { neasured by } \\
\text { l location, r }\end{array}$ & $\begin{array}{l}\text { lenote sign } \\
\text { clustered } \\
\text { firm- and } \\
\text { dummy), } \\
\text { pectively a }\end{array}$ & $\begin{array}{l}\text { ance on th } \\
\text { the firm le } \\
\text { ustry-level } \\
\text { dummy for } \\
\text { the Hirschy }\end{array}$ & $\begin{array}{l}10 \%, 5 \% \\
\text { All colu } \\
\text { ntrols (the } \\
\text { ollective, s } \\
\text { ann-Herfin }\end{array}$ \\
\hline
\end{tabular}

\subsection{Regressions on the Industry Level}

Since our innovation measure comes from the firm-level dataset but the market size effect is identified at the industry level, there may be a risk of underestimating the standard errors. Although we cluster standard errors at the industry-time level, a remaining concern is that observations may be correlated at the industry level over different periods. While clustering at the industry level would resolve this issue, this avenue is not possible due to an insufficient number of clusters. As a way to mitigate concerns, we check if the results are robust to collapsing all firm-level observations at the industry level and re-run our baseline regressions using a weighted least squares approach, using the number of firms within each industry as weights, as suggested by Angrist and Pischke (2009). In addition, we control for heteroscedasticity among error terms and report robust standard errors.

Table 6 displays similar regressions as shown with either TFP (Panel A) or labor productivity (Panel B) as the dependent variable. All specifications include the full set of 
industry and time fixed effects and the set of firm control variables collapsed at the industry level (firm size, age, region dummies, market competition, dummies for the ownership structures). The results are essentially similar as those shown in the tables above (with a slightly smaller magnitude). The OLS estimate of market size in Column (1) is smaller than the 2SLS estimate in Column (2) for both outcome variables. When we run separate industry-level regressions for samples containing only exporting (Column (3)) or nonexporting (Column (4)) firms, we can see that the market size effect for exporters is essentially zero. In contrast, income-growth-driven demand has a strong effect on nonexporting firms which is robust to including controls for exporting intensity and supply-side technology shocks (column (5)). For all 2SLS specifications (Column (2)-(5)), we report the F-statistic at the bottom of the table which is always above the critical threshold of 10 (Staiger \& Stock, 1997). These results are reassuring and provide additional credibility to the firm-level analysis.

Table 6: Industry level estimates

\begin{tabular}{lllllllll}
\hline \hline Method & OLS & & \multicolumn{5}{c}{ IV } \\
\cline { 2 - 5 } \cline { 5 - 8 } & $(1)$ & & $(2)$ & $(3)$ & $(4)$ & $(5)$ \\
\hline
\end{tabular}

A. Dependent variable: Log Total Factor Productivity

$\begin{array}{lccccc}\ln M S_{j, t, t+4}^{\text {actual }} & 0.009 & 0.169 & -0.130 & 0.315 & 0.327 \\ & (0.048) & (0.084)^{* *} & (0.103) & (0.089)^{* * *} & (0.090)^{* * *} \\ \text { R-squared } & 0.941 & 0.933 & 0.924 & 0.865 & 0.881 \\ \text { Observations } & 141 & 141 & 141 & 141 & 141\end{array}$

B. Dependent variable: Log Labor Productivity

\begin{tabular}{|c|c|c|c|c|c|}
\hline $\ln M S_{j, t, t+4}^{a c t u a l}$ & $\begin{array}{c}0.157 \\
(0.051)^{* * *}\end{array}$ & $\begin{array}{c}0.316 \\
(0.102)^{* * *}\end{array}$ & $\begin{array}{l}-0.019 \\
(0.121)\end{array}$ & $\begin{array}{c}0.431 \\
(0.102)^{* * *}\end{array}$ & $\begin{array}{c}0.422 \\
(0.102)^{* * *}\end{array}$ \\
\hline R-squared & 0.933 & 0.928 & 0.921 & 0.892 & 0.899 \\
\hline Observations & 141 & 141 & 141 & 141 & 141 \\
\hline F-Stats & & 37.3 & 26.6 & 64.9 & 63.8 \\
\hline Year and Industry FE & $\sqrt{ }$ & $\sqrt{ }$ & $\sqrt{ }$ & $\sqrt{ }$ & $\sqrt{ }$ \\
\hline $\begin{array}{l}\text { Firm controls } \\
\text { Export, Technology control }\end{array}$ & $\sqrt{ }$ & $\sqrt{ }$ & $\sqrt{ }$ & $\sqrt{ }$ & $\begin{array}{l}\sqrt{ } \\
\sqrt{ }\end{array}$ \\
\hline Sample & All & All & Exporters & \multicolumn{2}{|c|}{ Non-exporters } \\
\hline
\end{tabular}

\section{Conclusion}

Much of the previous literature studying determinants of the spectacular growth performance of the Chinese economy has focused on supply- and technology-factors, while the role of demand forces is still poorly understood. This paper focuses on firm's expectations about future market size as a potentially important channel that contributes to our understanding of technical progress in the Chinese manufacturing sector. The basic source of variation for potential market size comes from Chinese growth and its huge (and predictable) impact on the Chinese income distribution. In 1990, 71 percent of Chinese consumers had an income lower than 3594 Yuan (roughly 1025 US Dollar at constant 2011 prices) and were classified as low income households according to World Bank Classification. By the year 2011, this fraction had fallen to 21 percent. The associated change in the Chinese income distribution did not affect industries equally. To the extent that the Engel-curves for the industry's various products is non-linear, industries are affected differentially. It is this source of variation that underlies our identification strategy. 
To establish an empirical link between expected market size and technical progress, we combine household-expenditure data from Chinese Health and Nutrition Survey (CHNS) and firm-level data from the Annual Survey of Industrial Production (ASIP). Looking at 16 industries covering a substantial share of household expenditures for consumer durables, CHNS data allows us to construct product-specific Engel-curves for 16 consumer durables. Combining these income-driven changes in consumer behavior with information on the income distribution (income-class specific population shares) allows us to estimate a measure of expected market size, whose evolution over time is entirely driven by income growth. Using firm-specific productivity data estimated from ASIP data, we ask how firm performance is affected by expected market size. Our findings suggest that demand effects are quantitatively important: a one percent increase in expected market size increases firm-specific TFP by $0.46 \%$ and firm-specific labor productivity by $0.5 \%$. Firms in industries with a large expected local market are significantly more productive today, and show higher levels of other measures of innovative activity. We think that, in the future, the role of demand forces may become even stronger as a driver of Chinese growth than they were in in the recent past. China's share of private consumption in total GDP is still quite low by international standards and may converge to international levels in the future. Together with sustained economic growth, the size of the Chinese home market will become as important as the export market making Chinese firms less dependent on exports and let them focus more closely on the home market. Our results suggest that these dynamics from the demand side may have important implications for technical progress and may help to sustain high Chinese growth also in the years to come. 


\section{References}

Acemoglu, Daron. 2002. "Directed Technological Change." Review of Economic Studies, 69(4), 781-809.

Acemoglu, Daron and Fabrizio Zilibotti. 2001. "Productivity Differences." Quarterly Journal of Economics, 116(2), 563-606.

Acemoglu, Daron, and Joshua Linn. 2004. "Market Size in Innovation: Theory and Evidence from the Pharmaceutical Industry." Quarterly Journal of Economics, 119(8), 1049-90.

Acemoglu, Daron, Philippe Aghion, and Fabrizio Zilibotti. 2006a. "Distance to Frontier, Selection, and Economic Growth." Journal of the European Economic Association, $4(1), 37-74$.

Acemoglu, Daron, David Cutler, Amy Finkelstein, and Joshua Linn. 2006b. "Did Medicare Induce Pharmaceutical Innovation?" American Economic Review, 96(2): 10307.

Acemoglu, Daron, Philippe Aghion, Rachel Griffith, and Fabrizio Zilibotti. 2010. "Vertical Integration and Technology: Theory and Evidence." Journal of the European Economic Association, 8(5), 989-1033.

Acemoglu, Daron, Gino Gancia, and Fabrizio Zilibotti (2015). "Offshoring and Directed Technical Change." American Economic Journal: Macroeconomics, 7(3), 84-122.

Ackerberg, D. A., K. Caves, and G. Frazer. 2015. "Identification properties of recent production function estimators." Econometrica 83: 2411?2451.

Angrist, Joshua D., and Jörn-Steffen Pischke. 2009. Mostly Harmless Econometrics: An Empiricist's Companion. Princeton, New Jersey: Princeton University Press.

Arnold, Jens Matthias, and Katrin Hussinger. 2005. "Export Behavior and Firm Productivity in German Manufacturing: a Firm-Level Analysis." Review of World Economics, 141(2), 219-43.

Arvanitis, Spyridon, Thomas Bolli, Heinz Hollenstein, Marius Ch. Ley, and Martin Wörter. 2010. "Starke Position der Schweizer Wirtschaft im Internationalen Innovationswettbewerb." KOF Analysen, Zürich: 79-89.

Autor, David, Frank Levy, and Richard Murnane. 2003. "The Skill-Content of Recent Technological Change: An Empirical Investigation." Quarterly Journal of Economics, 118(4), 1279-1333.

Beerli, Andreas. 2010. "The Evolution of Durable Goods Demand During China's Transition - An Empirical Analysis of Household Survey Data from 1989 to 2006." IPCDP Working Paper 201.

Benjamin, Dwayne, Loren Brandt, and John Giles. 2005. "The Evolution of Income Inequality in Rural China." Economic Development and Cultural Change, 53(4), 769-824. 
Benjamin, Dwayne, Loren Brandt, John Giles, Sangui Wang. 2005b. "Income Inequality During China's Economic Transition." In China's Great Economic Transformation, ed. Loren Brandt Thomas G. and Rawski, 729-775. Cambridge, Massachusetts: Cambridge University Press.

Bloom, Nickolas, Raffaella Sadun, and John Van Reenen. 2012. "Americans Do IT Better: US Multinationals and the Productivity Miracle." American Economic Review, 102(1), 167 - 201.

Blume-Kohout, Margaret E., and Neeraj Sood. 2012. "Market size and innovation: Effects of Medicare Part D on pharmaceutical research and development." Journal of Public Economics, 97: 327-36.

Boppart, Timo. 2014. "Structural Change and the Kaldor Facts in a Growth Model with Relative Price Effects and Non-Gorman Preference." Econometrica, 82(6), 2167 - 96.

Boppart, Timo, and Franziska J. Weiss. 2013. "Non-homothetic Preferences and Industry Directed Technical Change." University of Zurich, Department of Economics Working Paper 123.

Brandt, Loren, Johannes Van Biesebroeck, and Yifan Zhang. 2011. "Creative Accounting or Creative Destruction? Firm-level Productivity Growth in Chinese Manufacturing." Journal of Development Economics, 97(2), 339-51.

Bureau of Economic Analysis. 2003. "Fixed Assets and Consumer Durable Goods in the United States, 1925 - 1999." BEA, Washington, DC.

Cameron, A. C., Gelbach, J. B., and Miller, D. L. (2011). Robust inference with multiway clustering. Journal of Business \& Economic Statistics, 29(2), 238-249.

Cotterill, Ronald W. 1986. "Market Power and the Retail Food Industry: Evidence from Vermont." Review of Economics and Statistics, 68(3), 379-86.

Crépon, Bruno, Emmanuel Duguet, and Jacques Mairessec. 1998. "Research, Innovation and Productivity: An Econometric Analysis at the Firm Level." Economics of Innovation and New Technology, 7(2), 115-58.

De Mouzon, Oliver, Pierre Dubois, Fiona Scott-Morton, and Paul Seabright. 2015. "Market Size and Pharmaceutical Innovation." Rand Journal of Economics, 46(4), 844871.

Draca, Mirko, Raffaella Sadun, and John Van Reenen. 2006. "Productivity and ICT: A Review of the Evidence," in Chrisanthi Avgerou, Robin Mansell, Danny Quah, and Roger Silverstone (eds.) Oxford Handbook of Information and Communication Technologies. Oxford.

Engel, Ernst. 1857. "Die Productions- und Consumptionsverhaeltnisse des Koenigsreichs Sachsen." Zeitschrift des Statistischen Bureaus des Königlich Sächsischen Ministeriums des Inneren, 8, 9.

Farrell, Joseph, and Carl Shapiro. 1990. "Asset Ownership and Market Structure in Oligopoly." RAND Journal of Economics, 21(2), 275-92. 
Farrell, Joseph, and Carl Shapiro. 1990. "Horizontal Mergers: An Equilibrium Analysis." American Economic Review, 80(1), 107-26.

Feenstra, Robert C., Zhiyuan Li, and Miaojie Yu. 2011. "Exports and Credit Constraints under Incomplete Information: Theory and Evidence from China." The Review of Economics and Statistics, 96(4), 729-744.

Finkelstein, Amy. 2004. "Static and Dynamic Effects of Health Policy: Evidence from the Vaccine Industry." Quarterly Journal of Economics, 119(2), 527-64.

Foellmi, Reto, and Josef Zweimüller. 2006. "Income Distribution and Demand-Induced Innovations." Review of Economic Studies, 73(4), 941- 60.

Gao, Jian, and Gary H. Jefferson. 2007. "Science and Technology Take-off in China? Sources of Rising R\&D Intensity." Asia Pacific Business Review, 13(3), 357 - 71.

Gancia, Gino, Andreas Müller, and Fabrizio Zilibotti. 2013. "Structural Development Accounting." In Advances in Economics and Econometrics: Theory and Applications (Tenth World Congress of the Econometric Society), D. Acemoglu, M. Arellano and E. Dekel (eds.), Cambridge University Press.

Griliches, Zvi. 1957. "Hybrid Corn: An Exploration in the Economics of Technological Change." Econometrica, 25(4), 501-22.

Feenstra, Robert C., Robert Inklaar and Marcel P. Timmer (2015), "The Next Generation of the Penn World Table" American Economic Review, 105(10), 3150-3182.

Holmes, Thomas J., Ellen R. McGrattan, and Edward C. Prescott (2015). "Quid Pro Quo: Technology Capital Transfers for Market Access in China." Review of Economic Studies, 82(3), 1154-1193.

Hsieh, Chang-Tai, and Peter J. Klenow. 2009. "Misallocation and Manufacturing TFP in China and India." Quarterly Journal of Economics, 124(4), 1403-48.

Hsieh, Chang-Tai, and Zheng M. Song. 2016. "Grasp the Large, Let Go of the Small: The Transformation of the State Sector in China." Brookings Papers on Economic Activity, 2015, 295-366.

Hu, Albert G. and Gary H. Jefferson. 2008 "A Great Wall of Patents: What is Behind China's Recent Patent Explosion?" Journal of Development Economics, 90(1), 57-68.

Jaravel, Xavier. 2016. "The Unequal Gains from Product Innovation: Evidence from the US Retail Sector." Mimeo, Stanford University.

Levinsohn, James, and Amil Petrin. 2003. "Estimating Production Functions Using Inputs to Control for Unobservables." Review of Economic Studies, 70(2), 317-41.

Liu, Haiyong. 2008. "The China health and nutrition survey: an important database for poverty and inequality research." The Journal of Economic Inequality, 6(4), 373-76.

Mairesse, Jacques, and Pierre Mohnen. 2010. "Using Innovations Surveys for Econometric Analysis", in: Hall, B. H. and Rosenberg, N. (eds), Handbook of the Economics of Innovation, Elsevier, Amsterdam, 1130-1155. 
Manjon Antolin, Miguel and Manez, Juan A., 2016 "Production function estimation in Stata using the Ackerberg?Caves?Frazer method."Stata Journal, 16 (4), 1046-1059

OECD. 2013. "OECD Science, Technology and Industry Scoreboard 2013." OECD: Paris.

Olley, G. Steven and Ariel Pakes. 1996. "The Dynamics of Productivity in the Telecommunications Equipment Industry." Econometrica, 64(6), 1263-98.

Song, Zheng, Kjetil Storesletten and Fabrizio Zilibotti. 2011. "Growing Like China." American Economic Review, 101(1), 202-41

Staiger, Douglas and James H. Stock. 1997. "Instrumental Variables Regression with Weak Instruments", Econometrica, 65(3), 557-86.

Van Reenen, John and Linda Yueh. 2012."Why Has China Grown So Fast? The Role of International Technology Transfer.” CEP Discussion Paper 1121.

World Bank. 2009. "Gross National Income Per Capita 2009, Atlas Method and PPP." The World Bank. http://www.damtp.cam.ac.uk/user/na/FoCM11/GNIPC.pdf (accessed 31.5.2012)

World Bank. 2014. "Research and Development Expenditure (\% of GDP)." The World Bank. http://data.worldbank.org/indicator/GB.XPD.RSDV.GD.ZS (accessed 10.01.2014)

Zilibotti, Fabrizio. 2017. "Growing and Slowing Down Like China." Journal of the European Economic Association, 15. 


\section{A Additional results and robustness}

Table A.1: Service Life and Depreciation Rates of Durable Goods

\begin{tabular}{lcl}
\hline \hline Durable good & Service Life $L_{j}$ & Category in BEA (2003) \\
\hline Air Condition & 11 & other household appliances \\
Camera & 10 & photographic equipment \\
Car & 8 & other motor vehicles \\
Cellphone & 9 & computer and peripheral equipment \\
Computer & 9 & computer and peripheral equipment \\
Bicycles & 10 & wheel goods \\
Electric Fan & 10 & other durable house furnishings \\
Refrigerator & 11 & kitchen and other household appliances \\
Homevideo appliances & 9 & video and audio products \\
Kitchen appliances & 11 & kitchen and other household appliances \\
Motorcycle & 8 & other motor vehicles \\
Radio & 9 & video and audio products \\
Satellite Dish & 10 & other durable house furnishings \\
Sewing Machine & 10 & other durable house furnishings \\
Telephone & 10 & other durable house furnishings \\
Washing Machine & 11 & kitchen and other household appliances \\
\hline \hline Notes: Source: BEA (2003)
\end{tabular}

Notes: Source: BEA (2003).

Table A.2: Correspondence between CHNS Durable Good Categories and ASIP Industries

\begin{tabular}{|c|c|c|c|c|}
\hline Durable good in CHNS & Industry in CIC & CIC prior 2003 & CIC post 2003 & Industry in analysis \\
\hline Air condition & Home air conditioner manufacturers & 4065 & 3952 & Air condition \\
\hline Bicycle & Bicycle manufacturers & 3740 & 3741 & bicycle \\
\hline Camera & Camera and equipment manufacturing & 4254 & 4153 & Camera \\
\hline Car & Automobile manufactoring & $3721-3725$ & 3721 & Car \\
\hline Cellphone & Mobile communications and terminal equipment manuf. & - & 4014 & Cellphone \\
\hline Colour TV & Home video equipment manufacturing & 4171 & 4071 & Homevideo appliances \\
\hline Computer & Computer machine manufacturing & 4141 & 4041 & Computer \\
\hline Dvd & Home video equipment manufacturing & 4171 & 4071 & Homevideo appliances \\
\hline Electric fan & Manuf. of household electrical appliances ventilation & 4064 & 3953 & Electric fan \\
\hline Refrigerator & Household refrigerating appliances manufacturing & 4063 & 3951 & Refrigerator \\
\hline Microwave & Household kitchen appliances manufacturing & 4066 & 3954 & Kitchen appliances \\
\hline Motorcycle & Motorcycle manufacturing & 3731 & 3731 & Motorcycle \\
\hline Presscooker & Household kitchen appliances with manufacturing & 4066 & 3954 & Kitchen appliances \\
\hline Radio & Home audio equipment manufacturing & 4172 & 4072 & Radio \\
\hline Ricecooker & Household kitchen appliances manufacturing & 4066 & 3954 & Kitchen appliances \\
\hline Satellite dish & Radio and television receiving equipment manufacturing & 4130 & 4032 & Satellite dish \\
\hline Sewing machine & Sewing machinery manufacturing & 3674 & 3653 & Sewing machine \\
\hline Telephone & Communication terminal equipment manufacturing & 4113 & 4013 & Telephone \\
\hline Tricycle & Bicycle manufacturing & 3740 & 3741 & Bicycle \\
\hline Washing machine & Household cleaning electrical appliances manufacturing & 4061,4062 & 3955 & Washing machine \\
\hline
\end{tabular}

Notes: This table show the correspondence between durable goods as available in the CHNS (first column) and the durable good producing industries in the ASIP data (column 3 and 4). 
Table A.3: Summary Statistics

\begin{tabular}{|c|c|c|c|c|}
\hline Variable & mean & sd & $\min$ & $\max$ \\
\hline \multicolumn{5}{|l|}{$A S I P$ data } \\
\hline $\ln T F P_{i, j, t}$ & 4.414 & 1.128 & -4.973 & 9.662 \\
\hline $\ln {\text { (Labor productivity })_{i, j, t}}$ & 3.937 & 1.185 & -5.481 & 9.584 \\
\hline $\ln M S_{j, t, t+4}^{a c t u a l}$ & 16.960 & 1.024 & 14.622 & 18.613 \\
\hline $\ln M S_{j, t, t+4}^{p, t+t+4 t i a l}$ & 16.680 & 1.188 & 14.259 & 18.280 \\
\hline $\ln (\# \text { workers })_{i, t}$ & 5.329 & 1.305 & 2.303 & 12.145 \\
\hline $1\left(\right.$ foreign owned $\left._{i, t}=1\right)$ & 0.331 & 0.470 & 0 & 1 \\
\hline $1\left(\right.$ state owned $\left._{i, t}=1\right)$ & 0.068 & 0.252 & 0 & 1 \\
\hline $1\left(\right.$ collective owned $\left._{i, t}=1\right)$ & 0.285 & 0.451 & 0 & 1 \\
\hline 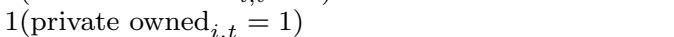 & .314 & .464 & 0 & 1 \\
\hline $1\left(A G E_{i, t}>\overline{A G E}\right)$ & 0.524 & 0.499 & 0 & 1 \\
\hline $1\left(C O A S T_{i, t}=1\right)$ & 0.848 & 0.359 & 0 & 1 \\
\hline$H H I_{j, t}$ & 692.099 & 559.312 & 91.232 & 2887.109 \\
\hline $1\left(\right.$ exports $\left._{i, t}>0\right)$ & 0.461 & 0.498 & 0 & 1 \\
\hline Share exporters upstream ${ }_{j, t}$ & 0.307 & 0.096 & 0.169 & 0.547 \\
\hline Share exporters in industry $_{j, t}$ & 0.461 & 0.142 & 0.116 & 0.851 \\
\hline \multicolumn{5}{|l|}{ Swiss manufacturing data (KOF Innovation Survey) } \\
\hline Share firms reporting high technology potential ${ }_{j, t}^{C H}$ & 0.435 & 0.280 & 0 & 1 \\
\hline Share firms reporting innovative activity ${ }_{j, t}^{C H}$ & 0.735 & 0.224 & 0.221 & 1 \\
\hline \multicolumn{5}{|l|}{ NBER-CES manufacturing data base } \\
\hline TFP index ${ }_{j, t}^{U S}$ & 1.930 & 4.105 & 0.764 & 37.520 \\
\hline
\end{tabular}

$\overline{\overline{N o t e s}: \ln T F P_{i, j, t} \text { denotes } \log \text { of total factor productivity of firm } i \text { in industry } j \text { and year } t \text {, estimated }}$ as described in Appendix B.2 $\ln$ (Labor productivity) ${ }_{i, j, t}$ is measured as the log of firm's value added over its number of employees. $\ln (\# \text { workers })_{i, t}$ the $\log$ of number of workers. $\ln M S_{j, t, t+4}^{a c t u a l}$ and $\ln M S_{j, t, t+4}^{\text {potential }}$ are actual and potential market size measured in log-terms, respectively and over a five year time horizon as described in the text. 1(foreign owned $\left.{ }_{i, t}=1\right), 1\left(\right.$ state $_{\text {owned }}, t=1$ ), $1\left(\right.$ collective owned $\left._{i, t}=1\right)$ and $1\left(\right.$ private owned $\left._{i, t}=1\right)$ indicate whether a firm is foreign owned, state owned, collectively owned or a domestic private enterprise, respectively. $1\left(A G E_{i, t}>\overline{A G E}\right)$ indicated whether a firm is above the median age of all firms in the sample. $1\left(C O A S T_{i, t}=1\right)$ is a dummy for whether a firm is located in a coastal province. $H H I_{j, t}$ is the Hirschmann-Herfindahl index as described in the text. 1(exports $s_{i, t}>0$ ) is a dummy for whether a firm has positive export sales. Share exporters upstream ${ }_{j, t}$ is the share of exporting firms in intermediate input producing firms of sector $j$ in year $t$ based on the Chinese Input-Output Table 2002. Share exporters in industry ${ }_{j, t}$ is the share of exporting firms in sector $j$ in year $t$. Share firms reporting high technology potential ${ }_{j, t}$ is the share of Swiss firms in sector $j$ reporting high worldwide technology potential as defined in the text. Share firms reporting innovative activity $_{j, t}$ is the share of innovating Swiss firms in sector $j$ and year $t$. TFP index $U_{j, t}^{U S}$ measures the change in TFP in US manufacturing industry $j$ in year $t$ relative to base year $1987^{\prime}$ (which is set to one).

Table A.4: Summary Statistics by Industry

\begin{tabular}{lccccc}
\hline \hline & Share exports & Share firms & \multicolumn{3}{c}{ Share firms owned } \\
\cline { 5 - 6 } Industry & on total sales & exporting & private & foreign & public or collective \\
\hline Air condition & 0.15 & 0.37 & 0.28 & 0.38 & 0.34 \\
Camera & 0.57 & 0.75 & 0.11 & 0.73 & 0.16 \\
Car & 0.02 & 0.19 & 0.09 & 0.15 & 0.75 \\
Cellphone & 0.28 & 0.50 & 0.23 & 0.58 & 0.19 \\
Computer & 0.27 & 0.39 & 0.17 & 0.45 & 0.38 \\
Bicycle & 0.30 & 0.50 & 0.41 & 0.33 & 0.26 \\
Electric Fan & 0.33 & 0.48 & 0.39 & 0.23 & 0.38 \\
Refrigerator & 0.14 & 0.39 & 0.34 & 0.22 & 0.44 \\
Homevideo appliances & 0.41 & 0.60 & 0.21 & 0.50 & 0.29 \\
Kitchen appliances & 0.34 & 0.51 & 0.51 & 0.28 & 0.21 \\
Motorcycle & 0.13 & 0.38 & 0.43 & 0.12 & 0.45 \\
Radio & 0.57 & 0.68 & 0.13 & 0.59 & 0.28 \\
Satellite Dish & 0.36 & 0.53 & 0.47 & 0.36 & 0.18 \\
Sewing Machine & 0.24 & 0.48 & 0.47 & 0.21 & 0.32 \\
Telephone & 0.29 & 0.44 & 0.20 & 0.45 & 0.35 \\
Washing machine & 0.26 & 0.54 & 0.41 & 0.29 & 0.31 \\
\hline
\end{tabular}

Notes: Descriptive statistics by durable good industry, pooled ASIP data 1998-2007. Column 2 shows the mean share of export sales on total sales. Column 3 shows the share of firms with positive export sales. Column 4 to 6 show the share of firms that are privately owned, foreign owned or in state or collective ownership. 
Table A.5: Usage Profiles, $u_{j, g}$ in 1997 of Income Groups

\begin{tabular}{|c|c|c|c|c|c|}
\hline \multirow[b]{2}{*}{ Durable Good } & \multicolumn{4}{|c|}{$\begin{array}{c}\text { Usage intensity in income group } \\
\text { (Ratio of group's usage intensity relative to lower group) }\end{array}$} & \multirow{2}{*}{$\begin{array}{l}\text { Income Group } \\
\text { with Largest Increase }\end{array}$} \\
\hline & Low & Low Middle & High Middle & High & \\
\hline \multirow[t]{2}{*}{ Air condition } & 0.004 & 0.010 & 0.026 & 0.047 & \\
\hline & & $(2.453)$ & $(2.444)$ & $(1.848)$ & low middle \\
\hline Camera & 0.005 & $\begin{array}{c}0.023 \\
(4.296)\end{array}$ & $\begin{array}{c}0.052 \\
(2.228)\end{array}$ & $\begin{array}{c}0.071 \\
(1.375)\end{array}$ & low middle \\
\hline \multirow[t]{2}{*}{ Car } & 0.003 & 0.003 & 0.008 & 0.027 & \\
\hline & & (1.072) & $(2.431)$ & $(3.506)$ & high \\
\hline \multirow[t]{2}{*}{ Cellphone } & 0.088 & 0.125 & 0.190 & 0.370 & \\
\hline & & $(1.420)$ & $(1.526)$ & $(1.947)$ & high \\
\hline \multirow[t]{2}{*}{ Computer } & 0.004 & 0.006 & 0.008 & 0.017 & \\
\hline & & (1.416) & (1.357) & (2.096) & high \\
\hline Bicycle & 0.294 & 0.357 & 0.486 & 0.499 & hiob middl \\
\hline \multirow[t]{2}{*}{ Electric Fan } & 0.296 & 0.386 & 0.516 & 0.639 & \\
\hline & & (1.307) & (1.336) & $(1.237)$ & high middle \\
\hline \multirow[t]{2}{*}{ Refrigerator } & 0.032 & 0.076 & 0.140 & 0.161 & \\
\hline & & (2.331) & (1.851) & (1.149) & low middle \\
\hline \multirow{2}{*}{ Homevideo appliances } & 0.076 & 0.128 & 0.190 & 0.216 & \\
\hline & & (1.674) & (1.485) & (1.136) & low middle \\
\hline \multirow[t]{2}{*}{ Kitchen appliances } & 0.130 & 0.228 & 0.332 & 0.442 & \\
\hline & & (1.756) & (1.460) & (1.328) & low middle \\
\hline \multirow[t]{2}{*}{ Motorcycle } & 0.017 & 0.033 & 0.052 & 0.073 & \\
\hline & & (1.908) & (1.586) & (1.399) & low middle \\
\hline \multirow[t]{2}{*}{ Radio } & 0.098 & 0.128 & 0.187 & 0.202 & \\
\hline & & (1.312) & $(1.454)$ & $(1.080)$ & high middle \\
\hline \multirow[t]{2}{*}{ Satellite Dish } & 0.018 & 0.021 & 0.019 & 0.020 & \\
\hline & & $(1.134)$ & $(0.908)$ & $(1.081)$ & low middle \\
\hline \multirow[t]{2}{*}{ Sewing Machine } & 0.102 & 0.131 & 0.157 & 0.165 & \\
\hline & & $(1.286)$ & (1.196) & $(1.053)$ & low middle \\
\hline \multirow[t]{2}{*}{ Telephone } & 0.025 & 0.063 & 0.130 & 0.175 & \\
\hline & & $(2.486)$ & $(2.078)$ & $(1.346)$ & low middle \\
\hline \multirow{2}{*}{ Washing machine } & 0.078 & 0.124 & 0.180 & 0.207 & \\
\hline & & $(1.584)$ & (1.458) & $(1.145)$ & low middle \\
\hline
\end{tabular}

Notes: Households are grouped into four income groups according their household income per capita in constant in constant 2011 Yuan and quartile thresholds of the pooled 1997-2006 income distribution: low income (below 2'293 Yuan), lower middle income (2'294- 4'539 Yuan), upper middle income (4'540 - 8'136 Yuan), high income (8'137 Yuan or more). The first row of each durable good shows usage intensities (the $\left.\bar{u}_{j, g}=u_{j, g, t=1997}\right)$, i.e. the average number of goods per capita. The second row shows the increase in the usage intensity (in brackets) moving from the income group below into the income group of that column. 
Table A.6: Effect of Market Size on Log Total Factor Productivity

Dependent variable: Log Total Factor Productivity

\begin{tabular}{|c|c|c|c|c|c|c|}
\hline \multirow[t]{2}{*}{ Method } & \multicolumn{3}{|c|}{$\overline{\mathrm{OLS}}$} & \multicolumn{3}{|c|}{ IV } \\
\hline & $(1)$ & $(2)$ & (3) & $(4)$ & $(5)$ & $(6)$ \\
\hline \multirow[t]{2}{*}{$\ln M S_{j, t, t+4}^{a c t u a l}$} & 0.116 & 0.070 & 0.070 & 0.472 & 0.349 & 0.349 \\
\hline & $(0.039)^{* * *}$ & $(0.038)^{*}$ & $(0.057)$ & $(0.064)^{* * *}$ & $(0.064)^{* * *}$ & $(0.089)^{* * *}$ \\
\hline \multirow{2}{*}{$\ln \left(\#\right.$ workers $\left._{i, t}\right)$} & & 0.087 & 0.087 & & 0.083 & 0.083 \\
\hline & & $(0.010)^{* * *}$ & $(0.013)^{* * *}$ & & $(0.010)^{* * *}$ & $(0.014)^{* * *}$ \\
\hline \multirow[t]{2}{*}{$1\left(\right.$ foreign owned $\left._{i, t}=1\right)$} & & 0.029 & 0.029 & & 0.028 & 0.028 \\
\hline & & $(0.025)$ & $(0.028)$ & & $(0.025)$ & $(0.028)$ \\
\hline \multirow[t]{2}{*}{$1\left(\right.$ state owned $\left._{i, t}=1\right)$} & & -0.466 & -0.466 & & -0.453 & -0.453 \\
\hline & & $(0.056)^{* * *}$ & $(0.061)^{* * *}$ & & $(0.057)^{* * *}$ & $(0.061)^{* * *}$ \\
\hline \multirow{2}{*}{$1\left(\right.$ collective owned $\left._{i, t}=1\right)$} & & 0.087 & 0.087 & & 0.082 & 0.082 \\
\hline & & $(0.025)^{* * *}$ & $(0.029)^{* * *}$ & & $(0.025)^{* * *}$ & $(0.030)^{* * *}$ \\
\hline \multirow{2}{*}{$1\left(a g e_{i, t} \geq \overline{a g e_{i, t}}\right)$} & & 0.396 & 0.396 & & 0.398 & 0.398 \\
\hline & & $(0.018)^{* * *}$ & $(0.020)^{* * *}$ & & $(0.018)^{* * *}$ & $(0.020)^{* * *}$ \\
\hline \multirow{2}{*}{$1\left(\right.$ coastal province $\left._{i, t}=1\right)$} & & -0.061 & -0.061 & & -0.063 & -0.063 \\
\hline & & $(0.036)^{*}$ & $(0.043)$ & & $(0.036)^{*}$ & $(0.043)$ \\
\hline \multirow[t]{2}{*}{$H H I_{j, t}$} & & -0.000 & -0.000 & & -0.000 & -0.000 \\
\hline & & $(0.000)^{*}$ & $(0.000)^{*}$ & & $(0.000)^{* * *}$ & $(0.000)^{* *}$ \\
\hline R-squared & 0.089 & 0.140 & 0.140 & 0.083 & 0.137 & 0.137 \\
\hline Observations & 25394 & 25394 & 25394 & 25394 & 25394 & 25394 \\
\hline F-Stats first stage & & & & 6643.921 & 5594.295 & 77.427 \\
\hline Year and Industry FE & $\sqrt{ }$ & $\sqrt{ }$ & $\sqrt{ }$ & $\sqrt{ }$ & $\sqrt{ }$ & $\sqrt{ }$ \\
\hline Firm controls & & $\sqrt{ }$ & $\sqrt{ }$ & & $\sqrt{ }$ & $\sqrt{ }$ \\
\hline 2 way clustering (firm, sector-year) & & & $\sqrt{ }$ & & & $\sqrt{ }$ \\
\hline \multicolumn{7}{|c|}{$\begin{array}{l}\text { Notes: }{ }^{* *} \mathrm{p}<0.01,{ }^{* *} \mathrm{p}<0.05,{ }^{*} \mathrm{p}<0.1 \text { denote significance on the } 10 \%, 5 \% \text { and } 1 \% \text { level, respectively. Standard } \\
\text { errors are clustered at the level of the firm in Column }(1),(2),(4),(5) \text { and two-way clustered at the level of the firm } \\
\text { and sector-year in Column }(3) \text { and }(6) \text {. All columns include year and industry fixed effects. Columns }(2)-(3) \text { and } \\
\text { (5)-(6) include a set of firm- and industry-level controls (the log of number of workers, age (measured by a dummy), } \\
\text { a dummy for collective, state and foreign ownership, coastal location, respectively and the Hirschmann-Herfindahl } \\
\text { index). } \ln M S_{j, t, t+4}^{\text {actual }} \text { is instrumented with } \ln M S_{j, t, t+4}^{\text {potential }} \text {. }\end{array}$} \\
\hline
\end{tabular}

Table A.7: Robustness to Omitting Single Durable Good Sectors

Dependent variable: Log Total Factor Productivity

\begin{tabular}{|c|c|c|c|c|c|c|c|c|}
\hline \multirow[t]{2}{*}{ Omitted industry } & $\begin{array}{l}\text { Air } \\
\text { Cond. }\end{array}$ & Camera & Car & $\begin{array}{l}\text { Cell- } \\
\text { phone }\end{array}$ & $\begin{array}{l}\text { Com- } \\
\text { puter }\end{array}$ & $\begin{array}{l}\text { Bi- } \\
\text { cycle }\end{array}$ & $\begin{array}{l}\text { Elect. } \\
\text { Fan }\end{array}$ & Refrig. \\
\hline & $(1)$ & (2) & (3) & (4) & (5) & (6) & (7) & (8) \\
\hline $\ln M S_{j, t, t+4}^{\text {actual }}$ & $\begin{array}{c}0.920 \\
(0.141)^{* * *}\end{array}$ & $\begin{array}{c}0.732 \\
(0.120)^{* * *}\end{array}$ & $\begin{array}{c}0.659 \\
(0.361)^{*}\end{array}$ & $\begin{array}{c}0.712 \\
(0.119)^{* * *}\end{array}$ & $\begin{array}{c}0.661 \\
(0.106)^{* * *}\end{array}$ & $\begin{array}{c}0.670 \\
(0.124)^{* * *}\end{array}$ & $\begin{array}{c}0.649 \\
(0.117)^{* * *}\end{array}$ & $\begin{array}{c}0.734 \\
(0.124)^{* * *}\end{array}$ \\
\hline $\begin{array}{l}\text { R-squared } \\
\text { Observations }\end{array}$ & $\begin{array}{l}0.182 \\
12562 \\
\end{array}$ & $\begin{array}{l}0.187 \\
13522 \\
\end{array}$ & $\begin{array}{c}0.171 \\
11523 \\
\end{array}$ & $\begin{array}{l}0.177 \\
13284 \\
\end{array}$ & $\begin{array}{l}0.181 \\
13011 \\
\end{array}$ & $\begin{array}{l}0.185 \\
11640 \\
\end{array}$ & $\begin{array}{l}0.193 \\
12976 \\
\end{array}$ & $\begin{array}{l}0.188 \\
13067 \\
\end{array}$ \\
\hline \multirow[t]{2}{*}{ Omitted industry } & $\begin{array}{l}\text { Homevid. } \\
\text { Appl. }\end{array}$ & $\begin{array}{l}\text { Kitchen } \\
\text { Appl. }\end{array}$ & $\begin{array}{l}\text { Motor- } \\
\text { cycle }\end{array}$ & Radio & $\begin{array}{l}\text { Sat. } \\
\text { Dish }\end{array}$ & $\begin{array}{l}\text { Sewing } \\
\text { Mach. }\end{array}$ & $\begin{array}{l}\text { Tele- } \\
\text { phone }\end{array}$ & $\begin{array}{l}\text { Washing } \\
\text { Mach. }\end{array}$ \\
\hline & (9) & (10) & (11) & (12) & (13) & (14) & (15) & (16) \\
\hline $\ln M S_{j, t, t+4}^{a c t u a l}$ & $\begin{array}{c}0.738 \\
(0.124)^{* * *}\end{array}$ & $\begin{array}{c}0.677 \\
(0.122)^{* * *}\end{array}$ & $\begin{array}{c}0.723 \\
(0.127)^{* * *}\end{array}$ & $\begin{array}{c}0.717 \\
(0.121)^{* * *}\end{array}$ & $\begin{array}{c}0.700 \\
(0.117)^{* * *}\end{array}$ & $\begin{array}{c}0.737 \\
(0.123)^{* * *}\end{array}$ & $\begin{array}{c}0.502 \\
(0.088)^{* * *}\end{array}$ & $\begin{array}{c}0.682 \\
(0.115)^{* * *}\end{array}$ \\
\hline R-squared & 0.183 & 0.192 & 0.189 & 0.187 & 0.186 & 0.186 & 0.196 & 0.188 \\
\hline Observations & 12861 & 12655 & 12612 & 13397 & 13493 & 12731 & 12945 & 13131 \\
\hline Year, Industry FE & $\sqrt{ }$ & $\sqrt{ }$ & $\sqrt{ }$ & $\sqrt{ }$ & $\sqrt{ }$ & $\sqrt{ }$ & $\sqrt{ }$ & $\sqrt{ }$ \\
\hline Firm controls & $\sqrt{ }$ & $\sqrt{ }$ & $\sqrt{ }$ & $\sqrt{ }$ & $\sqrt{ }$ & $\sqrt{ }$ & $\sqrt{ }$ & $\sqrt{ }$ \\
\hline Export, tech. controls & $\sqrt{ }$ & $\sqrt{ }$ & $\sqrt{ }$ & $\sqrt{ }$ & $\sqrt{ }$ & $\sqrt{ }$ & $\sqrt{ }$ & $\sqrt{ }$ \\
\hline
\end{tabular}

Notes: ${ }^{* * *} \mathrm{p}<0.01,{ }^{* *} \mathrm{p}<0.05,{ }^{*} \mathrm{p}<0.1$ denote significance on the $10 \%, 5 \%$ and $1 \%$ level, respectively. Standard errors are clustered at the firm level. All columns include year and industry fixed effects and show specifications for firms with non-exporters only. All columns include a set of firm- and industry-level controls: the log of number of workers, age (measured by a dummy), a dummy for collective, state and foreign ownership, coastal location, respectively, the Hirschmann-Herfindahl index, the share of exporters in a given industry and the industry-level TFP index from the NBER-CES manufacturing data base. $\ln M S_{j, t, t+4}^{a c t u a l}$ is instrumented with $\ln M S_{j, t, t+4}^{\text {potential }}$. 
Figure A.1: Dynamic in Usage Intensities for Given Income Groups
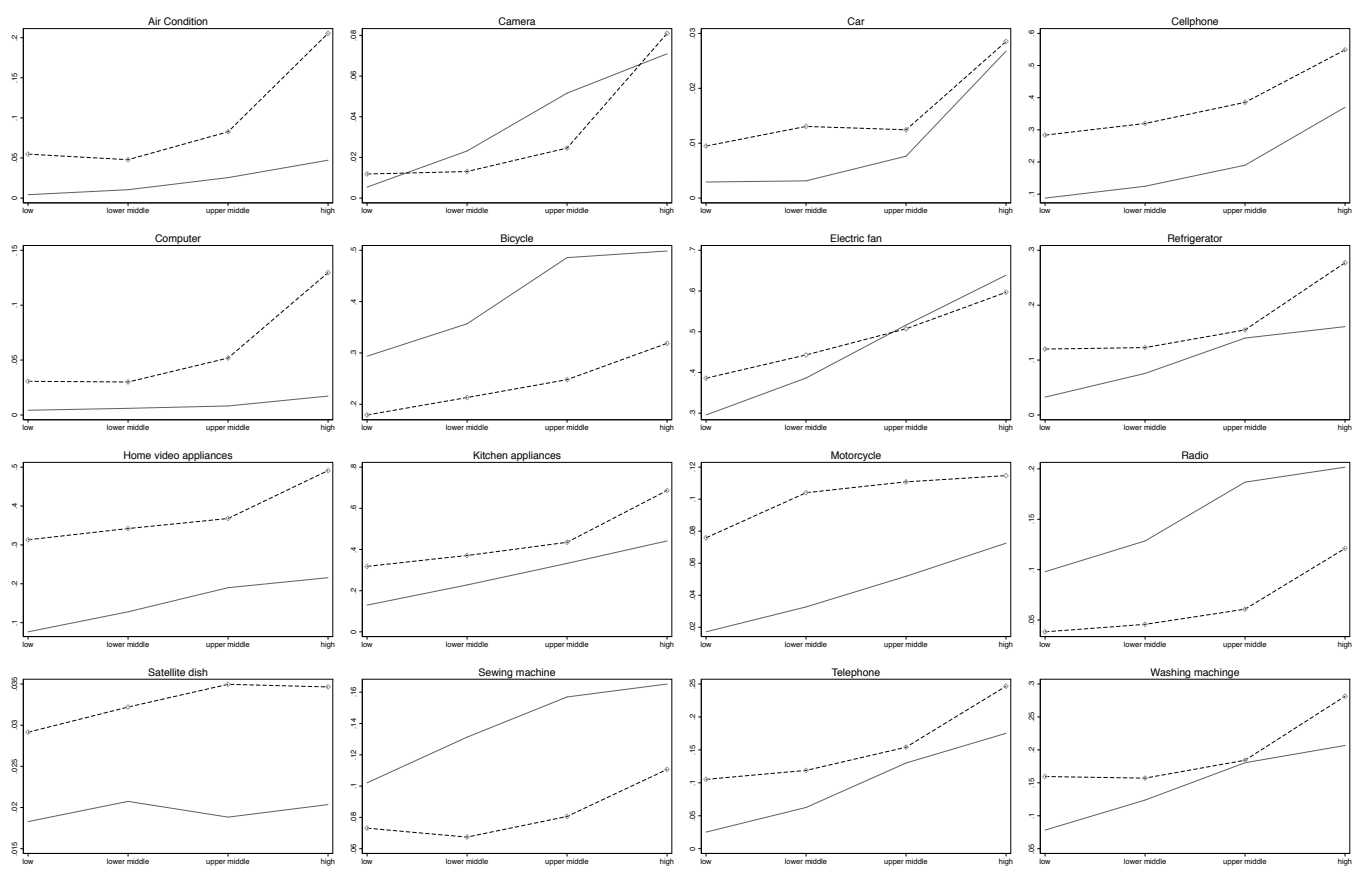

1997

$--\diamond \cdot--2009$

Notes: CHNS data. Usage per head on the y-axis (different scales), the four income groups on the x-axis in ascending order. The solid line represents the usage profile, $u_{j, g, t}$, in the first survey period available before our analysis period. For most goods this is 1997 whereas it is 2004 for cellphones and 2006 for satellite dishes. The dashed line represents the usage profile for the 2009 wave in the CHNS (2006 for radios). Income groups are defined as described in Section 3.2

Figure A.2: Share of Firms Engaging in Exports

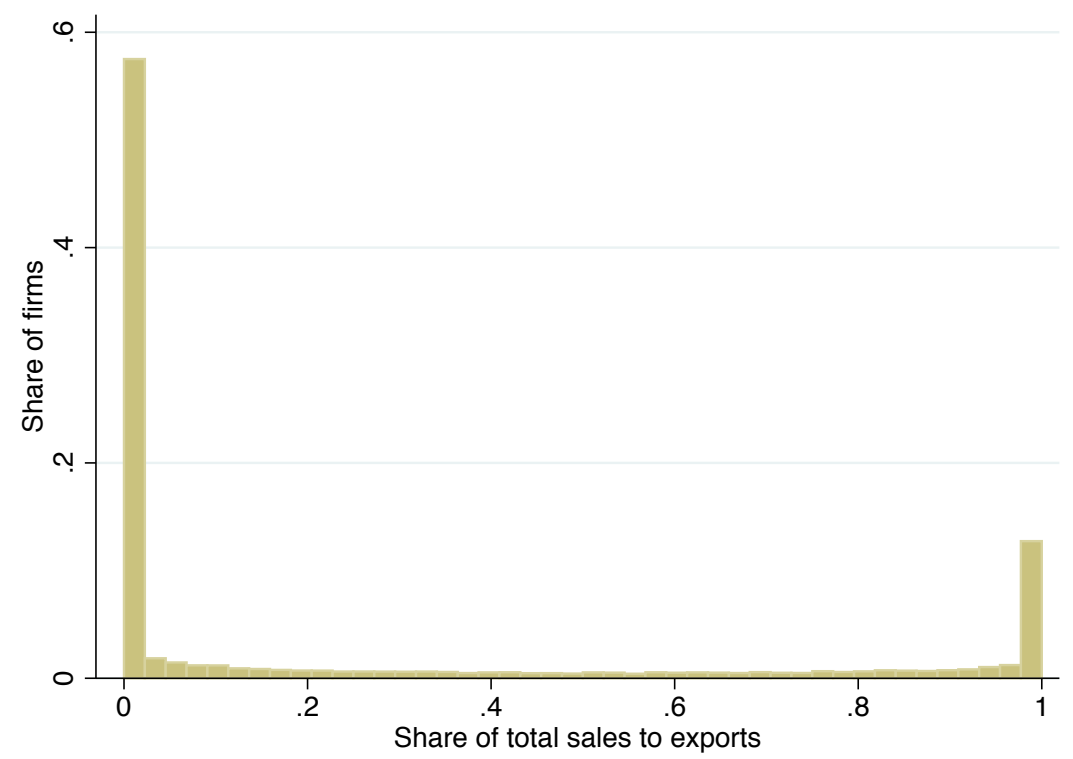

Notes: The figure plots the number of firms (in percentage terms) as a function of the export share relative to total firm sales. Data is based on the cleaned sample (see Section 2.2.). Source: ASIP dataset. 


\section{B Data Appendix}

\section{B.1 Measurement of Market Size}

In the CHNS we observe a household's ownership and change in ownership status of a specific durable good variety $j$ and without having information on its price and quality. Dealing with such a population measure of market size has some implications ${ }^{36}$ First, we can not distinguish between a car acquisition of one household to another household on a quality or price dimension 37 All acquisition within the same durable good variety $j$ receive the same (population) weight ${ }^{38}$ Thus, we think of the new car acquisition, which we observe in the CHNS, as an average car bought or a count measure of sales whose magnitude can only be compared across durable goods. Second and related, we can not distinguish between sales values of similar magnitude between different durable goods. A 1 percentage point sale of cars and a 1 percentage point sale of bicycles affects their respective industries with a similar magnitude although an average car differs from an average bicycle to a large extent in value terms.

\section{B.2 Construction of Total Factor Productivity at the Firm-level}

To construct a measure of firm-level productivity we follow an estimation procedure suggested by Ackerberg, Caves and Frazer (ACF, 2015). Their approach builds on previous work by Olley and Pakes (OP, 1996) and by Levinsohn and Petrin (LP, 2003) who suggested to use investment or intermediate inputs, respectively, as a proxy for unobserved shocks affecting a firm's input choice. One advantage of using intermediate inputs as proxy is strictly data driven as investment is zero for many firms in our dataset whereas intermediate inputs are not. As LP show, taking investment as proxy for unobserved productivity shocks is only valid for firms reporting non-zero investment. ACF, in turn, show that both the OP and LP approach may suffer from identification issues unless additional assumptions are made about the data-generating processes. ACF propose an alternative estimation strategy that draws on aspects OP and LP two-stage procedure but circumvents this functional dependence problem.

We use the STATA implementation acfest to estimate the parameters of the production function based on the ACF procedure (Manjon \& Manez, 2016):

$$
y_{i, t}=\beta_{0}+\beta_{w} \mathbf{w}_{i, t}+\beta_{s} \mathbf{s}_{i, t}+\omega_{i, t}+\eta_{i, t}
$$

where $y_{i, t}$ denotes the logarithm of real value added of firm $i$ in year $t$ and $\mathbf{w}_{i, t}$ denotes a vector of variable inputs and $\mathbf{s}_{i, t}$ a vector of state variables. Following the suggestions of Manjon and Manez (2016) we use the logarithm of real intermediate inputs, $m_{i, t}$, as proxy variable. Furthermore, we include the logarithm of the number of workers, $l_{i, t}$ in the vector of variable inputs and real capital, $k_{i, t}$ and a firm's age, $a_{i, t}$, (both in logs) in the vector of state variables. $\omega_{i, t}$ represents the unobserved productivity component and $\eta_{i, t}$ is an error term that is uncorrelated with input choices. The real capital stock variable was constructed following a procedure suggested by Brandt et al. (2011). Nominal values

\footnotetext{
${ }^{36}$ Note that Acemoglu and Linn (2004) use a similar population measure of drugs used in a certain age group.

${ }^{37}$ This also includes second hand markets.

${ }^{38}$ Note that also acquisitions across time cannot be distinguished, although a car bought in 1989 and one bought in 2009 might, technically speaking, be a very different durable good.
} 
of value added and the capital stock measure were deflated using the input- and outputdeflators provided by Brandt et al. (2011). The estimation yields $\hat{\beta}_{l}=0.54, \hat{\beta}_{k}=0.32$ and $\hat{\beta}_{a}=-0.5$ which can be used to back out the logarithm of TFP

$$
\hat{\omega}_{i, t}=y_{i, t}-\hat{\beta}_{l} l_{i, t}-\hat{\beta}_{k} k_{i, t}-\hat{\beta}_{a} a_{i, t}
$$

Note that we get a very similar estimates for the logarithm of TFP with use instead the LP method 39 All results presented in the paper are qualitatively similar using TFP based on LP.

\footnotetext{
${ }^{39}$ The correlation coefficient between both measures is $\rho=0.9$
} 